\title{
Circulating Activated Immune Cells as a Potential Blood Biomarkers of Non- small Cell Lung Cancer Occurrence and Progression
}

\author{
Yingyi Wang \\ Peking Union Medical College Hospital \\ Na Zhou \\ Peking Union Medical College Hospital \\ Rui Zhu \\ Peking Union Medical College Hospital \\ Xiaoyuan Li \\ Peking Union Medical College Hospital \\ Zhao Sun \\ Peking Union Medical College Hospital \\ Gao Yang \\ Peking Union Medical College Hospital \\ Wei Liu \\ Peking Union Medical College Hospital \\ Changting Meng \\ Seattle University \\ Yuping Ge \\ Peking Union Medical College Hospital \\ Chunmei Bai \\ Peking Union Medical College Hospital \\ Taisheng Li \\ Peking Union Medical College Hospital \\ Hongsheng Liu ( $\square$ lhs04391@163.com) \\ Peking Union Medical College Hospital
}

\section{Research Article}

Keywords: Immune cells, NSCLC, Cancer occurrence, Cancer progression, Clinicopathologic characteristics

Posted Date: May 13th, 2021

DOI: https://doi.org/10.21203/rs.3.rs-464238/v1

License: (9) (1) This work is licensed under a Creative Commons Attribution 4.0 International License. Read Full License 


\begin{abstract}
Background: Non-small cell lung cancer (NSCLC) has improved greatly in recent years. However, non-invasive early screening for carcinogenesis and progression are unclearly. The aim of this study was to explore the predictive value of peripheral blood immune cells in untreated NSCLC patients.
\end{abstract}

Methods: We retrospectively enrolled 305 untreated NSCLC patients and 132 healthy participators from February 2016 to August 2019 . Immune cells levels were performed by flow cytometry and blood routine tests.

Results: NSCLC patients had lower levels of T lymphocytes, NK cells, CD8+ T cells, naïve CD4+/ CD4+, naïve CD4+ T cells and higher levels of CD4+ T cells, memory CD4+/CD4+, memory CD4+ T cells, CD4+CD28+/CD4+, CD4+CD28+ T cells, CD8+CD28+/CD8+, CD8+HLA-DR+/CD8+, CD8+HLA-DR+ T

cells, $C D 8+C D 38+/ C D 8+, C D 8+C D 38+T$ cells and $C D 4+/ C D 8+$ than those in controls. Cancer progression were negatively associated with levels of $B$ cells CD4+ T cells, naïve CD4+/CD4+, naïve CD4+ T cells, CD4+CD28+ T cells, CD8+CD28+ T cells and positively associated with levels of NK cells, white blood cells (WBC), monocytes, neutrophils, eosinophils, basophils, monocytes to lymphocyte ratio (MLR), neutrophils to lymphocyte ratio (NLR), eosnophil to lymphocyte ratio (ELR), basophil to lymphocyte ratio (BLR), blood platelet to lymphocyte ratio (PLR) .

Conclusions: Abnormal levels of NK cells, CD4+ T cells, naïve CD4+/CD4+, naïve CD4+ T cells, CD4+CD28+ T cells can be used as independently predictive biomarker for non-invasive early screening in NSCLC occurrence and progression.

\title{
Background
}

Lung cancer is the leading cause of cancer-related incidence and mortality worldwide (respectively, $11.6 \%$ and $18.4 \%$ of the total cases) $(1,2)$. NSCLC accounts about $80-85 \%$ of lung cancers with 5 -year survival rate less than $15 \%$ for advancing cancer $(3,4)$. 5 -year survival ranged from 50 to $80 \%$ for early stage NSCLC treated with surgical resection. However, early diagnosis of NSCLC is lower than $20 \%$ (5). Improving the accuracy of prediction could contribute to performed a better treatment strategy (6). Thus, it is important for identifying markers to predict the cancer progression of patients with lung cancer upon noninvasive method.

In recent years, the role of immune system has been an increasing recognition in cancer development and progression. Immune cells play critical roles in the anti-tumor response basing on promoting or suppressing tumor progression and subsequent invasion and metastasis (7). To identify new predictive marker, tumor infiltrating T-lymphocytes has become a hot topic of research and several research had demonstrated the predictive role in cancer (8). However, the detection of TILs is complex and cannot be dynamically monitored. In this context, a lot of focus had been on peripheral blood, which as the main source of immune cells, has several advantages including simpler handling, noninvasive, and the possibility of dynamic monitoring.

Several studies have reported the levels and roles of peripheral blood lymphocyte subsets in NSCLC, such as B cell, CD4+ T cells, and CD4/CD8 ratio (9, 10). The relationship between lymphocyte subsets and gender, age and stage also were reported (11). However, the predictive values of immune cells in untreated lung cancer patients are not well studied. In this study, we analyzed peripheral blood immune cells to provide basic data for further exploration of tumor predictive indicators.

\section{Methods}

\section{Patients and clinical data}

437 participants were recruited in Peking Union Medical College Hospital (PUMCH) between February 2016 and August 2019 and had not received anti-tumor therapies before enrollment. 305 untreated NSCLC patients (141male and 164 female) were selected with ages between 25 and 84 years (mean age: 59.67 years). 135 patients had no active disease with surgery before diagnosed lung cancer and 43 patients had receive two surgery. 211 patients had conformed history of diseases before diagnosed lung cancer including 142 patients suffered two disease. 84 patients had smoking history with 1 to 63 years including smoking cessation of 51 patients from 0.1 to 30 years. 67 patients had a drinking history including abstinence for 10 patients. 132 age-and sex-matched healthy volunteers ( 96 men and 53 women) were selected with age from 25 to 80 years (mean age: 59.19 years). Age was divided into three groups upon World Health Organization (Yong:0-44 years; Middle people:45-59 years; Elderly people: over 59 year). Clinical data of untreated are summarized in Table 1. All participants had informed consent. This study was approved by the Ethical Committee of PUMCH (JS-1405).

\section{Flow cytometry and blood routine tests}

Lymphocyte immunophenotyping were identified by three-color flow cytometry (Epics XL flow cytometry; Bechman Coulter, USA). Specific monoclonal antibodies against CD19, CD16CD56, CD4, CD8, CD45RO, CD45RA, CD28, HLA-DR, CD38 were used to identify lymphocyte subsets. Dual-platform method was performed to calculate lymphocyte subsets upon WBC counts. Inflammatory cell including lymphocyte, monocyte, neutrophil, eosinophil, basophil, red blood cells (RBC), hemoglobin, platelet were acquired from blood routine tests of the same sample.In addition, the levels of MLR, NLR, ELR, BLR, red blood cells to lymphocyte ratio (RLR), hemoglobin to lymphocyte ratio (HLR), and PLR were evaluated.

\section{Statistical analysis}

Statistical analysis was performed using SPSS 22.0 software (IBM Corporation, USA) and GraphPad Prism 7.0 software (San Diego, USA). The data were expressed using means \pm standard deviation. Kolmogorov-Smirnov test was performed for the distribution test. Normally distributed were analyzed by t-test 
and one-way analysis. Non-parametric data were compared by Mann-Whitney test and Kruskal-Wallis. Spearman's rank correlation test were used for correlation analysis. Probability value was performed 2 -sided tests and $p<0.05$ was considered statistically significant.

\section{Results}

\section{Analytical assessment of predictive value of immune parameters in tumorigenesis of NSCLC}

To explore the predictive role of immune cells in untreated NSCLC patients, a total of 487 Chinese adults (305 lung cancer patients and 132 healthy controls) were enrolled in this study. We did not analyze inflammatory cells due to lack these data for controls. It is verified that levels of lymphocyte subsets were significantly associated with gender and age in healthy controls and cancer patients, thus we carefully avoided age- and sex-related biases.

We compared levels of immune cells in all patients and controls based on t-test and Mann-Whitney test. In this study, low levels of $\mathrm{T}$ lymphocytes ( $p<0.001)$, NK cells $(p<0.001)$, CD8+ T cells $(p=0.008)$, naïve CD4+/CD4+ $(p<0.001)$, and naïve CD4+ T cells $(p<0.001)$ was observed in lung cancer patients compared to controls. However, levels of CD4+T cells $(p=0.042)$, memory CD4+/CD4+ $(p<0.001)$, memory CD4+ T cells $(p<0.001), \mathrm{CD} 4+\mathrm{CD} 28+/ \mathrm{CD} 4+(p<0.001)$,

CD4+CD28+ T cells $(p=0.002), \mathrm{CD} 8+\mathrm{CD} 28+/ \mathrm{CD} 8+(p=0.004), \mathrm{CD} 8+\mathrm{HLA}-\mathrm{DR}+/ \mathrm{CD} 8+(p<0.001), \mathrm{CD} 8+\mathrm{HLA}-\mathrm{DR}+\mathrm{T}$ cells $(p=0.022), \mathrm{CD} 8+\mathrm{CD} 38+/ \mathrm{CD} 8+(p<0.001)$, CD $8+C D 38+T$ cells $(p=0.001)$ and CD4+/CD8+ $(p<0.001)$ were higher in patients than those in controls. There is no significant difference for $B$ cells and CD $8+$ CD28+ T cells counts between patients and controls ( $p>0.05)$. The result was shown in table 2.

\section{Predictive value of immune parameters in NSCLC progression}

To further analyze the role of immune cells in NSCLC progression, the 305 NSCLC patients were divided into 4 group by the stages. In this study, a trend of decrease in B cells counts ( $r=-0.193, p=0.001$, Fig. $1 A)$, CD4+ T cells counts $(r=-0.135, p=0.020$, Fig. $1 C)$, naïve $C D 4+/ C D 4+$ percentage $(r=-0.122, p=0.037, F i g$. 1D), naïve CD4+ T cells counts ( $r=-0.144, p=0.013$, Fig. 1E), CD4+CD28+ T cells counts $(r=-0.137, p=0.019$, Fig. 1F), and CD8+CD28+ T cells counts ( $r=-0.186$, $p=0.001$, Fig. $1 \mathrm{G}$ ) was noted for patients with advancing stage. On the contrary, there were increasingly advancing stage related trend for NK cells counts $(\mathrm{r}=0.117, p=0.045$, Fig. 1B), WBC counts $(\mathrm{r}=0.177, p=0.002$, Fig. $1 \mathrm{H})$, monocytes $(\mathrm{r}=0.186, p=0.001$, Fig. 1I), neutrophils $(\mathrm{r}=0.158 p=0.007$, Fig. $1 \mathrm{~J})$, eosinophils $(\mathrm{r}=0.171, p=0.003$, Fig. 1K), basophils $(r=0.203, p<0.001$, Fig. 1L), MLR $(r=0.206, p<0.001$, Fig. 1M), NLR $(r=0.165, p=0.005$, Fig. $1 \mathrm{~N})$, ELR $(r=0.188, p=0.001$, Fig 10), BLR ( $r=0.230, p<0.001$, Fig. 1P), PLR ( $r=0.121, p=0.038$, Fig. 1Q). There were no significant correlation between other immune cells levels and advancing stages (Supplementary Table 1). Noteworthily, stage Il patients had highest levels of T lymphocytes, NK cells, CD4+ T cells, CD8+ T cells, memory CD4+ T cells, CD4+CD28+ T cells, CD8+CD28+ T cells, CD8+HLA-DR+ T cells, lymphocytes and lowest counts of WBC, neutrophils than those in other stages.

\section{Correlation of immune cells levels with clinicopathologic characteristics}

To further demonstrate the relationship between immune cells levels and clinicopathologic characteristics based on t text, Mann-Whitney test for 2 group, and Spearman's rank correlation test for more than 2 groups, which was summarized in Table $3-4$ and figure 2-3. There are high B cells counts ( $p<0.001)$ and CD8+CD28+/CD8+ percentage $(p=0.047)$ in female patients than those in male. On the contrary, we discovered low counts of WBC $(p=0.005)$, monocytes $(p<0.001)$, neutrophils $(p=0.001)$, eosinophils $(p=0.006), \operatorname{RBC}(p<0.001)$, hemoglobins $(p<0.001)$, and $\operatorname{MLR}(p<0.001), \operatorname{NLR}(p=0.001), \operatorname{ELR}(p=0.002), \operatorname{HLR}$ $(p=0.007)$ in female patients compared to those in male patients. Although there are significant difference for $B$ cells counts $(p=0.018), C D 8+C D 28+T$ cells $(p=0.026)$ and $C D 8+H L A-D R+/ C D 8+$ percentage $(p=0.033)$ in patients with allergic history than those in patients without allergic history, we only discovered significant difference for those data between patients with allergic history except antibiotic and patients without allergic. Low CD $8+C D 28+/ C D 8+$ percentage $(p=0.008), C D 4+/ C D 8+$ ratio $(p=0.039)$, and high percentage of CD8+HLA-DR+ T cells $(p=0.019), C D 8+C D 38+/ C D 8+(p=0.016), C D 8+C D 38+T$ cells $(p=0.013)$, RBC $(p=0.001)$, hemoglobins $(p<0.001)$ were discovered in patients with surgery than patients without surgery. Patients with history of diseases had higher CD4+CD28+/CD4+ percentage $(\mathrm{p}=0.043)$ and lower $\mathrm{CD} 8+\mathrm{CD} 38+/ \mathrm{CD} 8+$ percentage $(p=0.012), \mathrm{CD} 8+\mathrm{CD} 38+\mathrm{T}$ cells $(p=0.022)$ than those in patients without diseases. There were significant difference for memory CD4+/CD4+ percentage $(p=0.034)$, naïve CD4+/CD4+ percentage $(p=0.034), \mathrm{CD} 8+\mathrm{CD} 28+\mathrm{T}$ cells $(p=0.031)$, and monocytes $(p=0.002)$ in various histology. Patients with distant metastases had lower levels of B cells $(p=0.001), \mathrm{CD} 4+\mathrm{T}$ cells $(p=0.040)$, naïve CD4+ T cells ( $p=0.049), C D 4+C D 28+/ C D 4+(p=0.040), C D 4+C D 28+T$ cells $(p=0.015), C D 8+C D 28+T$ cells $(p=0.001)$ and higher counts of NK cells $(p=0.049)$, $\operatorname{WBC}(p=0.003)$, monocytes $(p=0.011)$, neutrophils $(p=0.004)$, eosinophils $(p=0.003)$, basophils $(p=0.001)$, RBC $(p=0.034)$, platelets $(p=0.013)$, and ratio of MLR $(p=0.003), \operatorname{NLR}(p=0.002), \operatorname{ELR}(p<0.001), \operatorname{BLR}(p<0.001), \operatorname{PLR}(p=0.011)$ than those in patients without distant metastases.

A trend of decreased CD8+CD28+/CD8+ percentage $(r=-0.170, p=0.006$, Fig. 2A), CD8+CD38+/CD8+ percentage $(r=-0.264, p<0.001$, Fig. 2B), and increased CD8+HLA-DR+/CD8+ percentage ( $r=0.179, p=0.002$, Fig. $2 C)$ with ages were found in our study. However, we did not find the similar trend in RBC and hemoglobins in spite of statistically significant difference $(r=-0.047, p=0.416 ; r=0.004, p=0.943)$ for these data. There were increased WBC ( $r=0.227, p<0.001$, Fig. 2D), monocytes ( $r=0.293, p<0.001$, Fig. 2E), neutrophils ( $r=0.207, p<0.001$, Fig. 2F), RBC ( $r=0.194, p=0.001$, Fig. 2G), hemoglobins ( $r=0.277$, $p<0.001$, Fig. $2 \mathrm{H})$, and MLR ( $\mathrm{r}=0.226, p<0.001$, Fig. $2 \mathrm{l}), \mathrm{NLR}(\mathrm{r}=0.150, p=0.011$, Fig. $2 \mathrm{~J})$ with the various status of smoking history. In addition, we also found patients with smoking cessation had low $B$ cells counts $(r=-0.082, p=0.166)$ compared to that in patients with smoking or without smoking. There were a decreased trend in B cells counts $(\mathrm{r}=-0.139, p=0.018$, Fig. $2 \mathrm{~K})$ and increased trend in WBC ( $\mathrm{r}=0.146, p=0.013$, Fig. $2 \mathrm{~L})$, monocytes counts $(\mathrm{r}=210, p<0.001$, Fig. $2 \mathrm{M})$, hemoglobins counts ( $\mathrm{r}=0.194, p=0.001$, Fig. $2 \mathrm{~N})$ and MLR ( $\mathrm{r}=0.200, p<0.001$, Fig. 20) with various status of drinking history. A trend of increase in WBC $(\mathrm{r}=0.198, p=0.001$, Fig. 2P), neutrophils ( $\mathrm{r}=0.174, p=0.003$, Fig. $2 \mathrm{Q})$, and platelets $(\mathrm{r}=0.140, p=0.017$, Fig. $2 \mathrm{R})$ was found with increased ECOG.

Tumor stages were negatively associated with counts of B cells $(r=-0.216, p<0.001$, Fig. 3A), CD 4+ T cells $(r=-0.117, p=0.047$, Fig. 3B), CD8+CD28+ T cells $(\mathrm{r}=-0.142, p=0.016$, Fig. $3 \mathrm{C})$ and positively associated with counts of WBC ( $r=0.117, p=0.048$, Fig. 3D), monocytes ( $r=0.165, p=0.005$, Fig. 3E), neutrophils

Page $3 / 16$ 
$(\mathrm{r}=0.120, p=0.043$, Fig. 3F), eosnophils ( $\mathrm{r}=0.165, p=0.005$, Fig. 3G), basophils $(\mathrm{r}=0.175, p=0.003$, Fig. 3H), platelets $(\mathrm{r}=0.125, p=0.035$, Fig. 3l), and MLR $(r=0.242, p<0.001$, Fig. 3J), NLR ( $r=0.196, p=0.001$, Fig. 3K), ELR ( $r=0.208, p<0.001$, Fig. 3L), BLR $(r=0.220, p<0.001$, Fig. 3M). However, there are no significant correlation between lymphocytes counts $(r=-0.110, p=0.063)$ and tumor stages. There were negative correlation for $B$ cells counts ( $r=-0.174, p=0.003$, Fig. $3 N)$, CD8+CD28+ T cells counts ( $r=-0.167, p=0.005$, Fig. 30) with lymph nodes metastases. But an increases trend with lymph nodes metastases in WBC counts $(\mathrm{r}=0.181, p=0.002$, Fig. 3P), neutrophils counts ( $\mathrm{r}=0.137, p=0.021$, Fig. 3Q), MLR ( $\mathrm{r}=0.231, p<0.001$, Fig. 3R), NLR ( $\mathrm{r}=0.187, p=0.002, \mathrm{Fig} .3 \mathrm{~S}), \mathrm{ELR}(\mathrm{r}=0.161$, $p=0.006$, Fig. $3 \mathrm{~T}), \mathrm{BLR}(\mathrm{r}=0.222, p<0.001$, Fig. $3 \mathrm{U})$, and PLR $(\mathrm{r}=0.152, p=0.010$, Fig. $3 \mathrm{~V})$ was discovered in this study. We did not find the relationship between other cells and clinicopathologic characteristics.

\section{Discussion}

To our knowledge, this is the most comprehensive report to evaluate both predictive value for the immune cells in cancer occurrence and progression, and the relationship between clinical outcomes and immune cells in patients with NSCLC. We discovered that abnormal levels of NK cells, CD4+ T cells, naïve CD4+/CD4+, naïve CD4+ T cells, CD4+CD28+ T cells can predict NSCLC occurrence and progression.

The growing understanding of immune mechanisms in cancer suggest highly complex immune interactions in cancer occurrence and progression. In addition, several researches had demonstrated the importance of inflammatory responses in tumor development by inhibiting apoptosis and promoting angiogenesis and the relationship between inflammatory responses and immune surveillance, responses to therapy in tumor treatment $(12,13)$. Detecting immune cells (lymphocyte subsets and inflammatory cells) levels might contribute to clinical diagnosis of diseases, provide evidence for the pathogenesis, progression and predict prognosis of disease $(14,15)$.

Several reports have been demonstrated the predictive role for lymphocyte subsets in cancers, however, those results are controversial and not comprehensive. We evaluated the predictive role of lymphocytes subsets in carcinogenesis. In this study, we found decreased levels of $T$ lymphocytes, NK cells, CD $8+T$ cells, naïve CD4, and elevated levels of CD4+ T cells, memory CD4, CD4+CD28+/CD4, CD4+CD28+ T cells, CD8+CD28+/CD8+, CD8+HLA-DR+/CD8+, CD8+ HLA-DR+ $T$ cells, CD8+CD38+/CD8+, CD8+CD38+ T cells and CD4+/CD8+ can be a predictive marker in carcinogenesis, which is consistent with other articles $(13,16$, 17). However, conflicting results have also been reported in several studies, such as high CD8+ $T$ cells and decreased CD4+ $T$ cells counts, $C D 4+/ C D 8+$ ratio were discovered in patients with NSCLC than those in controls (18). CD8+ T cells and CD4+ T cells undergo a period of massive expansion, activation, differentiation into effector cells, and apoptosis, which might lead to these disparate results. T lymphocytes play the mainly mediated role in direct and indirect effect of cell immunity (19). NK cells contribute to the innate immune system at the first line defence, which kill tumor cells by producting cytotoxicity and cytokine in the absence of antibodies or major histocompatibility complex (MHC) class I molecules (20). CD8+ T cells as cytotoxic cells, directly kill cancer cells by recognizing antigen presented in the context of $\mathrm{MHC}$ class I molecules and secreting cytolytic granules and chemokines, including perforin (21). As the cytotoxicity cells, low NK cells counts and CD8+ T cells counts might imply that weakened immunological system contributes to growth of cancer cells by reducing effectively killing effect towards the cancer cells. CD4+ T cells can eliminate tumor cells by expressing MHC class II molecules, enhance antitumor responses of CD8+ T cells, and promote the proliferation and differentiation B cells (22-24). Naïve CD4+ T cells are immature and inactivated cells which have not encountered their cognate antigens, which are activated following encounter with antigen and differentiated into effector $\mathrm{T}$ cells and memory $T$ cells (25). Memory CD4+ T cells induce faster and stronger immune responses during secondary encounter with pathogens compared with the primary response to infection (26). As the helper cells, decreased naïve CD4+/CD4+ percentage and increased CD4+T cells counts, memory CD4+/CD4+ percentage might suggest that the anti-tumor immune response was activated and naïve $C D 4+T$ cells were differentiated into $C D 4+T$ cells and memory $C D 4+T$ cells. CD28 are a very important co-stimulatory marker, which is required as a secondary signal for activated CD $8+T$ cells and CD4+ $T$ cells exerting anti-tumor response (27). We discovered patients had high CD4+CD28+/CD4+ percentage and CD4+CD28+ T cells counts than those in controls, which might imply that CD4+ $T$ cells were activated in cancer occurrence. Noteworthily, patients had high CD8+CD28+/CD8+ percentage than that in controls, but there are no relationship between patients and controls. Those results might imply that the activation CD8+ T cells was limited, as a result cancer occurrence based on the reducing anti-tumor response. HLA-DR and CD38, as markers of CD8+ T cell activation, play a crucial predictive value in CD8+ T cells activation and CD4+ $T$ cells depletion (28). Elevated levels of HLA-DR and CD38 suggested the immune system was activated during tumorigenesis. The CD4+/CD8+ ratio is a marker of cell-mediated immunity in cancer patients (29). Decreased ratio is reported to link with a low immunological function (30).

Immune status is closely associated with the pathogenesis and development of cancer. Less research has been reported on the role of peripheral blood immune cells in cancer progression, which focus on B cells, NK cells, CD4+ T cells, CD8+ T cells and CD4+/CD8+ (13, 17). In addition, there is no consensus regarding change of lymphocyte subsets in the cancer progression. Liang et al reported that there was decreased trend in counts of NK cells, CD4+ $T$ cells and CD4+/CD8+ ratio with advanced NSCLC (including stage III, IV and controls groups), and no relationship between CD8+ T cells and stage (17). Mazzoccoli et al reported that there were decreasing trend for $B$ cells and increasing trend for NK cells in cancer stage (13). Those results were not exactly the same as ours. In our study, cancer progression were negatively associated with levels of B cells, CD4+ T cells, naïve CD4+/CD4+, naïve CD4+ T cells, CD4+CD28+ T cells, CD8+CD28+ T cells and positively associated with NK cells, WBC counts, monocytes, neutrophils, eosinophils, basophils, MLR, NLR, ELR, BLR, PLR. A possible explanation for this finding could be immune function disorder associated with clinical staging. B cells can recognize antigens, regulate process and presentation of antigen, present antigens, provide co-stimulation, in part, are important for regulating fate decisions in T cells (31). As to our results of lymphocyte subsets might suggest that immune function is severely damaged with advancing stage causing growth and metastasis of cancer cells. The reason is likely that decreased expression of co-stimulatory molecule (CD28) can suppress anti-tumor response by limiting aggregation of CD4+ T cells, CD8+ $T$ cells and immune system were not activated during cancer progression due to no significant difference for HLA and CD38 in each stage. WBC and neutrophils can contrubite to cancer progression and metastasis, which could reflect the tumor burden in patients (32). Lymphocytes take part in host cellmediated immunity regulation based on destructing residual malignant cells and related micrometastases(33). Monocytes can promote angiogenesis, tumorigenesis, and the development of malignant cells and suppress anti-tumor responses (34). As a marker of acute and chronic inflammation, peripheral neutrophils are a key mediators in tumor progression due to promote tumor growth, stimulate angiogenesis, and favor cancer cells' invasive behavior (35). 
Increased neutrophil levels might inhibit the antitumor effects of T cells and NK cells (36). There are dual role of eosinophils in cancer development and progression. On the one hand, eosinophils can modulate adaptive and innate immune responses based on interacting with mast cells and $\mathrm{T}$ cells which stimulates the expansion of CD4+ T lymphocytes by inducing to express MHC II molecule (37). On the other hand, eosinophils can promote cancer growth by inducing production of Th2 cell responses (37). Basophils play a dual role in allergic reactions, promotion of humoral and cell-mediated memory immune responses, regulation of Th2 cell responses (38). Platelets play an important role in tumor angiogenesis, which might adhere to tumor vessels and release granules (12). MLR reflects the host's immune homeostasis and the tumor microenvironment (39). Increased NLR levels represents increased inflammation and decreased immune reaction (36). Several reports have been demonstated that the change of WBC, monocytes, neutrophils, eosinophils, basophils, MLR, NLR, ELR, BLR, PLR were associated with cancer prognosis in some solid tumors $(37,40)$. However, there is no reported for the predictive value of those cells in cancer occurrence and progression. In this study, results about elevated levels of inflammatory cells might demonstrate that those cells play an important role in anti-tumor response and can predict cancer progression not just prognosis. In short, those immune cells are gradually destroyed with advancing cancer, which restricts the recognition and killing of cancer cells and triggers the extensive dissemination of cancer cells.

It is interesting to observe that there were highest levels of T lymphocytes, NK cells, CD4+ T cells, CD8+ T cells, memory CD4+ T cells, CD4+CD28+ T cells, CD8+CD28+ T cells, CD8+HLA-DR+ T cells, lymphocytes and lowest counts of WBC, neutrophils in stage II NSCLC patients than those in other stage. The reason is likely that low quantitative levels of immunity contributes to carcinogenesis. Whereafter, immune system recognizes the "alien species" and mobilize all immune cells to kill cancer cells by expression of CD28, HLA-DR, CD38 which promotes activated and expanded effector cell. After a period of time, immune cells present depletion and fails to kill cancer cells leading to decline immune cells levels and cancer growth and metastasis.

There are several limitations in this study, such as limited numbers of patients with stage II and III and inhomogenous clinicopathologic characteristics of samples. Despite these limitations, this study demonstrated that immune cells play a predictive role in the NSCLC development and progression.

In summary, lower levels of T lymphocytes, NK cells, CD8+ T cells, naïve CD4+/ CD4+ and higher percentage of CD4+ T cells, memory CD4+/CD4+, CD4+CD28+/CD4+, CD4+CD28+ T cells , CD8+CD28+/CD8+, CD8+HLA-DR+/CD8+, CD8+HLA-DR+ T cells, CD8+CD38+/CD8+, CD8+ CD38+ T cells, and CD4+/CD8+ can be independently predictive biomarker of NSCLC occurrence. NSCLC progression can be predicted by decreased levels of B cells, CD4+ T cells, naïve CD4+/CD4+, naïve CD4+ T cells, CD4+CD28+ T cells, CD8+CD28+ T cells and increased levels of NK cells, WBC, monocytes, neutrophils, eosinophils, basophils, MLR, NLR, ELR, BLR, PLR. Furthermore, immune cells levels were associated with gender, age, allergic history, surgery, history of diseases, smoking history, drinking history, ECOG, histology, tumor stage, lymph nodes, and distant metastases.

\section{Abbreviations}

NSCLC: Non-small cell lung cancer; WBC, white blood cells; MLR, monocytes to lymphocyte ratio; NLR, neutrophils to lymphocyte ratio; ELR, eosnophil to lymphocyte ratio; BLR, basophil to lymphocyte ratio; PUMCH, Peking Union Medical College Hospital; RBC, red blood cells; RLR, red blood cells to lymphocyte ratio ; HLR, hemoglobin to lymphocyte ratio;

\section{Declarations}

\section{Ethics approval:}

This study was approved by the Ethical Committee of Ethical Committee of PUMCH (JS-1405). All methods were performed in accordance with the relevant guidelines and regulations.

\section{Consent for publication:}

NOT APPLICABLE

\section{Availability of data and materials:}

The datasets used and/or analyzed during the current study are available from the corresponding author upon reasonable request.

\section{Competing interests:}

The authors declare that they have no conflict of interest.

\section{Funding :}

This study was supported by grants from CAMS Initiative for Innovative Medicine (No. 2017-I2M-4-002; No. 2016-I2M-1-001), PUMC Youth Fund

(No.2017320001) and National Natural Science Fundation of China (No. 81472785; No. 61435001).

\section{Authors' contributions:}


The experiments were conceived and designed by Yingyi Wang, Hongsheng Liu, and Taisheng Li. Manuscript was written by Yingyi Wang, Na Zhou, Rui Zhu. Diagnose of all NSCLC were performed by Yingyi Wang, Wei Liu and Hongsheng Liu. Sample processing and experiments were performed by Zhao Sun, Gao

Yang. Data entry were performed by Xiaoyuan Li, Changting Meng.Data were analysed and interpreted by Yuping Ge, and Rui Zhu.

\section{Acknowledgements:}

We thank all the members in Department of Medical Oncology of Peking Union Medical College Hospital for their help and valuable opinion.

\section{References}

1. Duruisseaux M, Esteller M. Lung cancer epigenetics: From knowledge to applications. Seminars in Cancer Biology. 2017.

2. Bray F, Ferlay J, Soerjomataram I, Siegel R, Torre L, Jemal A. Global cancer statistics 2018: GLOBOCAN estimates of incidence and mortality worldwide for 36 cancers in 185 countries. CA: a cancer journal for clinicians. 2018;68(6):394-424.

3. Osmani L, Askin F, Gabrielson E, Li QK. Current WHO guidelines and the critical role of immunohistochemical markers in the subclassification of non-small cell lung carcinoma (NSCLC): Moving from targeted therapy to immunotherapy. Semin Cancer Biol. 2018;52(Pt 1):103-9.

4. Xiao T, Bao L, Ji H. Finding biomarkers for non-small cell lung cancer diagnosis and prognosis. Frontiers in Biology. 2012;7(1):14-23.

5. Reibnitz DV, Shaikh F, Wu AJ, et al. Stereotactic body radiation therapy (SBRT) improves local control and overall survival compared to conventionally fractionated radiation for stage I non-small cell lung cancer(NSCLC). Acta Oncologica. 2018:1-7.

6. Liu K, Zhao K, Wang L, Sun E. The prognostic values of tumor-infiltrating neutrophils, lymphocytes and neutrophil/lymphocyte rates in bladder urothelial cancer. Pathology - Research and Practice. 2018:S0344033818303522.

7. Yuan Y, Jiang Y-C, Sun C-K, Chen Q-M. Role of the tumor microenvironment in tumor progression and the clinical applications (Review). Oncology Reports. 2016;35(5).

8. Karn T, Pusztai L, Rody A, Holtrich U, Becker S. The Influence of Host Factors on the Prognosis of Breast Cancer: Stroma and Immune Cell Components as Cancer Biomarkers. Current Cancer Drug Targets. 2015;15(8):652-64.

9. Erfani N, Mehrabadi SM, Ghayumi MA, et al. Increase of regulatory T cells in metastatic stage and CTLA-4 over expression in lymphocytes of patients with non-small cell lung cancer (NSCLC). Lung Cancer. 2012;77(2):306-11.

10. Saavedra D, García B, Lorenzo-Luaces P, et al. Biomarkers related to immunosenescence: relationships with therapy and survival in lung cancer patients. Cancer immunology, immunotherapy : CII. 2016;65(1):37-45.

11. Kuss I, Hathaway B, Ferris RL, Gooding W, Whiteside TL. Decreased absolute counts of T lymphocyte subsets and their relation to disease in squamous cell carcinoma of the head and neck. Clin Cancer Res. 2004;10(11):3755-62.

12. Yuan C, Li N, Mao X, Liu Z, Ou W, Wang SY. Elevated pretreatment neutrophil/white blood cell ratio and monocyte/lymphocyte ratio predict poor survival in patients with curatively resected non-small cell lung cancer: Results from a large cohort. Thoracic Cancer. 2017;8(4):350-8.

13. Mazzoccoli G, Parrella P, Muscarella LA, et al. Comparison of circadian characteristics for cytotoxic lymphocyte subsets in non-small cell lung cancer patients versus controls. Clinical \& Experimental Medicine. 2012;12(3):181-94.

14. Krupnick AS, Kreisel D, Szeto WY, Popma SH, Rosengard BR. Multiparameter flow cytometric approach for simultaneous evaluation of T lymphocyte ndothelial cell interactions. Cytometry. 2001;46(5):271-80.

15. Jia Y, Xu L, Lin Q, et al. Levels of lymphocyte subsets in peripheral blood prior treatment are associated with aggressive breast cancer phenotypes or subtypes. Medical Oncology. 2014;31(6):981.

16. Liu C, Hu Q, Hu K, et al. Increased CD8+CD28+ T cells independently predict better early response to stereotactic ablative radiotherapy in patients with lung metastases from non-small cell lung cancer. Journal of Translational Medicine.

17. L Y, F Z, H L, et al. Circulating Tumor Cells Were Associated with the Number of T Lymphocyte Subsets and NK Cells in Peripheral Blood in Advanced NonSmall-Cell Lung Cancer. Disease markers. 2017;2017(undefined):5727815.

18. Liu C, Wu S, Meng X, Liu G, et al. Predictive value of peripheral regulatory T cells in non-small cell lung cancer patients undergoing radiotherapy. Oncotarget. 2017;8(26): 43427-38.

19. Y C, H L, M L, et al. Salvia miltiorrhiza polysaccharide activates T Lymphocytes of cancer patients through activation of TLRs mediated -MAPK and -NF-KB signaling pathways. Journal of ethnopharmacology. 2017;200(undefined):165-73.

20. Li Y, Sun R. Tumor immunotherapy: New aspects of natural killer cells. Chinese Journal of Cancer Research. 2018;30(2):173.

21. Knocke S, Fleischmann-Mundt B, Saborowski M, Manns MP, Kühnel F, Wirth TC, et al. Tailored Tumor Immunogenicity Reveals Regulation of CD4 and CD8 T Cell Responses against Cancer. Cell reports. 2016;17(9):2234-46.

22. Akhmetzyanova I, Zelinskyy G, Schimmer S, et al. Tumor-specific CD4+ T cells develop cytotoxic activity and eliminate virus-induced tumor cells in the absence of regulatory T cells. Cancer immunology, immunotherapy : ClI. 2013;62(2):257-71.

23. Zhang L, Qian W, Chen Q, Yin L, Li B, Wang H. Imbalance in circulating T lymphocyte subsets contributes to Hu antibody-associated paraneoplastic neurological syndromes. Cellular Immunology. 2014;290(2):245-50.

24. Zhi-Chun D, Gang Z. Cytotoxic chemotherapy and CD4+ effector T cells: an emerging alliance for durable antitumor effects. Clinical \& Developmental Immunology. 2012;2012(2):890178. 
25. Ivanova EA, Orekhov AN. T Helper Lymphocyte Subsets and Plasticity in Autoimmunity and Cancer: An Overview. BioMed research international. 2015;2015:327470.

26. Mckinstry KK, Strutt TM, Swain SL. The potential of CD4 T-cell memory. Insect Science. 2010;130(1):1-9.

27. Qin L, Jing X, Qiu Z, et al. Aging of immune system: Immune signature from peripheral blood lymphocyte subsets in 1068 healthy adults. Aging. 2016;8(5):848-59.

28. Onlamoon N, Tabprasit S, Suwanagool S, Louisirirotchanakul S, Ansari AA, Pattanapanyasat K. Studies on the potential use of CD38 expression as a marker for the efficacy of anti-retroviral therapy in HIV-1-infected patients in Thailand. Virology. 2005;341(2):238-47.

29. Xu J, Jiang L, Cao H, Jia Y, et al. Predictive Value of CD4+/CD8+ Ratio in Patients with Breast Cancer Receiving Recombinant Human Thrombopoietin. Journal of Interferon \& Cytokine Research the Official Journal of the International Society for Interferon \& Cytokine Research. 2018.

30. Wen-Jing W, Zhen T, Wei G, Li-Hua S. Variation of blood T lymphocyte subgroups in patients with non- small cell lung cancer. Asian Pacific Journal of Cancer Prevention Apjcp. 2013;14(8):4671-3.

31. Tsou P, Katayama H, Ostrin EJ, Hanash SM. The Emerging Role of B Cells in Tumor Immunity. Cancer Research. $2016 ; 76(19): 5597$.

32. Hao L, Zhang J, Di Y, Tan Z. Prognostic Value of White Blood Cells Detected for the First Time After Adjuvant Chemotherapy in Primary Operable NonSmall Cell Lung Cancer. Technology in cancer research \& treatment. 2018;17(undefined):1533033818802813.

33. Sarraf KM, Belcher E, Raevsky E, Nicholson AG, Goldstraw P, Lim E. Neutrophil/lymphocyte ratio and its association with survival after complete resection in non-small cell lung cancer. Journal of Thoracic \& Cardiovascular Surgery. 2009;137(2):425-8.

34. Gabrilovich DI, Srinivas N. Myeloid-derived suppressor cells as regulators of the immune system. Nature Reviews Immunology. 2009;9(3):162.

35. Galdiero MR, Garlanda C, Jaillon S, Marone G, Mantovani A. Tumor associated macrophages and neutrophils in tumor progression. Journal of Cellular Physiology. 2013;228(7):1404-12.

36. Feng F, Sun L, Zheng G, et al. Low lymphocyte-to-white blood cell ratio and high monocyte-to-white blood cell ratio predict poor prognosis in gastric cancer. Oncotarget. 2017;8(3):5281-91.

37. Sakkal S, Miller S, Apostolopoulos V, Nurgali K. Eosinophils in Cancer: Favourable or Unfavourable? Current Medicinal Chemistry. 2016;23(7): 650-66.

38. Sektioglu IM, Carretero R, Bulbuc N, Bald T, Tüting T, Rudensky AY. Basophils Promote Tumor Rejection via Chemotaxis and Infiltration of CD8+ T Cells. Cancer research. 2017;77(2):291-302.

39. Ching-Liang H, Chieh-Sheng L, Jia-Hong C, Yu-Guang C, Tzu-Chuan H, Yi-Ying W. Neutrophil/Lymphocyte Ratio, Lymphocyte/Monocyte Ratio, and Absolute Lymphocyte Count/Absolute Monocyte Count Prognostic Score in Diffuse Large B-Cell Lymphoma: Useful Prognostic Tools in the Rituximab Era. Medicine. 2015;94(24):e993.

40. Valero C, Pardo L, López M, García J, Camacho M, Quer M, et al. Pretreatment count of peripheral neutrophils, monocytes, and lymphocytes as independent prognostic factor in patients with head and neck cancer. Head \& Neck. 2017;39(2):219.

\section{Tables}

Table 1

Clinicophthological characterstics of the untreated lung cancer patients in this study 


\begin{tabular}{|c|c|c|}
\hline Characterstics & & $N=305$ \\
\hline \multirow[t]{2}{*}{ Gender } & Male & 141 \\
\hline & Female & 164 \\
\hline \multirow[t]{3}{*}{ Age } & Yong & 25 \\
\hline & Middle & 116 \\
\hline & Elder & 164 \\
\hline \multirow[t]{4}{*}{ Allergic history } & Antibiotic & 31 \\
\hline & Other & 6 \\
\hline & No allergic & 239 \\
\hline & Unkown & 29 \\
\hline \multirow[t]{8}{*}{ Surgery } & Uterine & 27 \\
\hline & Caesarean section & 11 \\
\hline & Epityphlon & 24 \\
\hline & Thyroid & 17 \\
\hline & Intestines & 13 \\
\hline & Other & 86 \\
\hline & No surgery & 146 \\
\hline & Unkown & 24 \\
\hline \multirow[t]{8}{*}{ History of diseases } & Hypertension & 110 \\
\hline & Diabetes & 40 \\
\hline & Coronary heart disease & 21 \\
\hline & Thyroid nodule & 19 \\
\hline & Fatty liver & 11 \\
\hline & Other & 152 \\
\hline & No Medical & 75 \\
\hline & Unkown & 19 \\
\hline \multirow[t]{4}{*}{ Smoking history } & Yes & 33 \\
\hline & Cessation & 51 \\
\hline & No & 193 \\
\hline & Unkown & 19 \\
\hline \multirow[t]{4}{*}{ Drinking history } & Yes & 57 \\
\hline & Abstinence & 10 \\
\hline & No & 219 \\
\hline & Unkown & 19 \\
\hline \multirow[t]{5}{*}{ ECOG PS } & 0 & 247 \\
\hline & 1 & 35 \\
\hline & 2 & 9 \\
\hline & 3 & 2 \\
\hline & Unkown & 12 \\
\hline \multirow[t]{3}{*}{ Histology } & Adenocarcinoma & 277 \\
\hline & Squamous carcinoma & 27 \\
\hline & Adenosquamous carcinoma & 1 \\
\hline \multirow[t]{2}{*}{ Stage } & I & 203 \\
\hline & ॥ & 18 \\
\hline
\end{tabular}

Page $8 / 16$ 


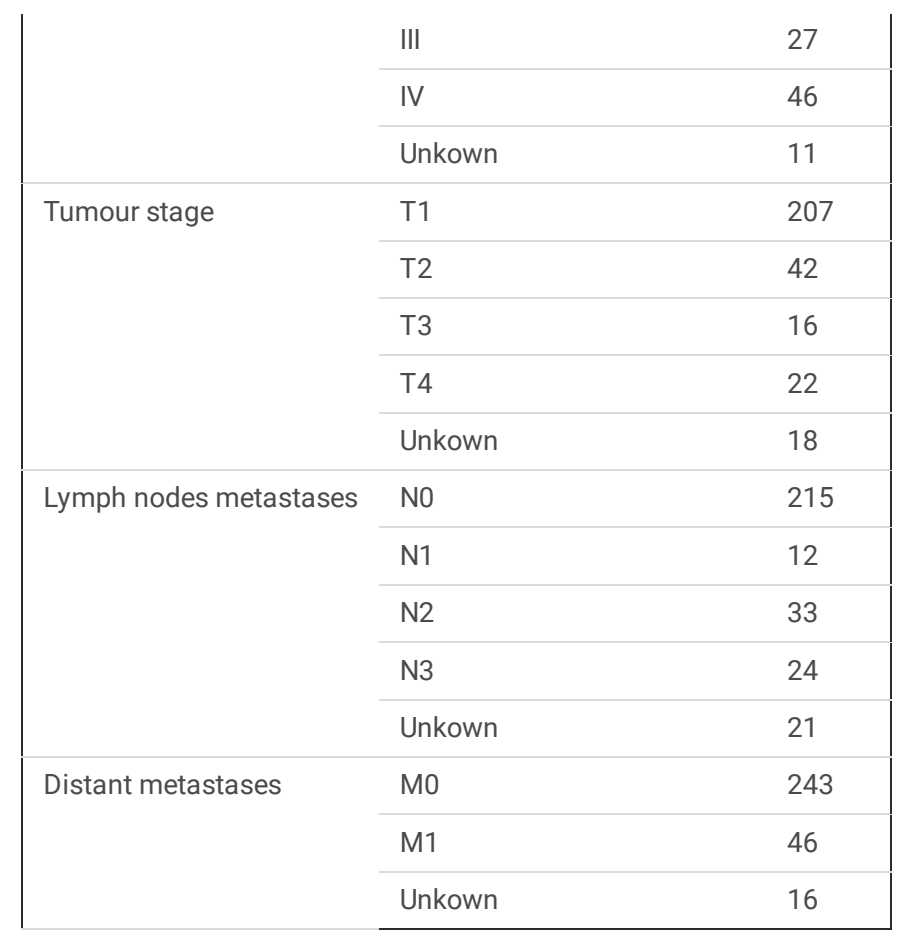

Table 2

Differences of immune parameters in untreated lung cancer patients and healthy controls

\begin{tabular}{|c|c|c|c|}
\hline Lymphocyte subsets & Healthy controls $(\mathrm{N}=132)$ & Lung cancer patients $(\mathrm{N}=357)$ & $P$ value \\
\hline T Lymphocyte (cells/10^12ul) & $1.97 \pm 0.53$ & $1.73 \pm 0.61$ & $<0.001$ \\
\hline B cells (cells/ul) & $201.69 \pm 91.56$ & $184.85 \pm 98.29$ & 0.054 \\
\hline NK cells (cells/ul) & $390.99 \pm 251.48$ & $269.15 \pm 213.78$ & $<0.001$ \\
\hline CD4+ T cells (cells/ul) & $689.83 \pm 255.28$ & $745 \pm 302.8$ & 0.042 \\
\hline CD8+ T cells (cells/ul) & $511.43 \pm 255.09$ & $439.25 \pm 212.9$ & 0.008 \\
\hline Memory CD4+/CD4+ (\%) & $65.89 \pm 13.8$ & $73.55 \pm 12.88$ & $<0.001$ \\
\hline Memory CD4+ T cells (cells/ul) & $441.8 \pm 166.31$ & $539.09 \pm 220.41$ & $<0.001$ \\
\hline Naïve CD4+/CD4+ (\%) & $34.11 \pm 13.8$ & $24.21 \pm 12.2$ & $<0.001$ \\
\hline Naïve CD4+ T cells (cells/ul) & $248.05 \pm 160.27$ & $183.7 \pm 128.13$ & $<0.001$ \\
\hline CD4+CD28+/CD4+ (\%) & $87.12 \pm 10.97$ & $92.42 \pm 8.95$ & $<0.001$ \\
\hline CD4+CD28+ T cells (cells/ul) & $600.64 \pm 239.99$ & $674.78 \pm 271.48$ & 0.002 \\
\hline CD8+CD28+/CD8+ (\%) & $50.95 \pm 15.54$ & $55.84 \pm 17.26$ & 0.004 \\
\hline CD8+CD28+T cells (cells/ul) & $249.24 \pm 119.32$ & $230.43 \pm 106.65$ & 0.156 \\
\hline CD8+HLA-DR+/CD8+ (\%) & $28.4 \pm 10.7$ & $38.37 \pm 14.13$ & $<0.001$ \\
\hline CD8+HLA-DR+ T cells (cells/ul) & $148.75 \pm 102.86$ & $175.18 \pm 129.29$ & 0.022 \\
\hline CD8+CD38+/CD8+ (\%) & $22.34 \pm 14.71$ & $31.04 \pm 13.35$ & $<0.001$ \\
\hline CD8+CD38+ T cells (cells/ul) & $114.11 \pm 96.19$ & $136.43 \pm 95.69$ & 0.001 \\
\hline $\mathrm{CD} 4+/ \mathrm{CD} 8+(\%)$ & $1.62 \pm 0.91$ & $1.97 \pm 1.00$ & $<0.001$ \\
\hline
\end{tabular}

Table 3

relationship between lymphocytes levels and clinicopathologic characteristics

Page 9/16 


\begin{tabular}{|c|c|c|c|c|c|c|c|c|c|c|c|}
\hline & & $\begin{array}{l}\text { T } \\
\text { lymphocytes } \\
\text { (cells/ul) }\end{array}$ & $\begin{array}{l}\text { B cells } \\
\text { (cells/ul) }\end{array}$ & $\begin{array}{l}\text { NK cells } \\
\text { (cells/ul) }\end{array}$ & $\begin{array}{l}\text { CD4+ T } \\
\text { cells } \\
\text { (cells/ul) }\end{array}$ & $\begin{array}{l}\text { CD8+ T } \\
\text { cells } \\
\text { (cells/ul) }\end{array}$ & $\begin{array}{l}\text { Memory } \\
\text { CD4+/CD4+ } \\
(\%)\end{array}$ & $\begin{array}{l}\text { Memory } \\
\text { CD4+ T } \\
\text { cells } \\
\text { (cells/ul) }\end{array}$ & $\begin{array}{l}\text { Naïve } \\
\text { CD4+/ } \\
\text { CD4+ } \\
(\%)\end{array}$ & $\begin{array}{l}\text { Naïve } \\
\text { CD4+ T } \\
\text { cells } \\
\text { (cells/ul) }\end{array}$ & $\begin{array}{l}\text { CD4+CD28 } \\
(\%)\end{array}$ \\
\hline \multirow[t]{3}{*}{ Gender } & Male & $\begin{array}{l}1220.79 \pm \\
428.8\end{array}$ & $\begin{array}{l}162.41 \pm \\
92.49\end{array}$ & $\begin{array}{l}294.41 \pm \\
257.20\end{array}$ & $\begin{array}{l}733.74 \pm \\
329.37\end{array}$ & $\begin{array}{l}443.59 \pm \\
215.88\end{array}$ & $\begin{array}{l}74.40 \pm \\
13.31\end{array}$ & $\begin{array}{l}532.37 \pm \\
227.24\end{array}$ & $\begin{array}{l}22.94 \\
\pm \\
11.97\end{array}$ & $\begin{array}{l}169.68 \pm \\
122.10\end{array}$ & $91.99 \pm 9.6$ \\
\hline & Female & $\begin{array}{l}1277.29 \pm \\
474.83\end{array}$ & $\begin{array}{l}204.14 \pm \\
99.30\end{array}$ & $\begin{array}{l}247.43 \pm \\
165.50\end{array}$ & $\begin{array}{l}754.67 \pm \\
278.59\end{array}$ & $\begin{array}{l}435.51 \pm \\
210.90\end{array}$ & $\begin{array}{l}72.81 \pm \\
12.50\end{array}$ & $\begin{array}{l}544.86 \pm \\
214.89\end{array}$ & $\begin{array}{l}25.30 \\
\pm \\
12.32\end{array}$ & $\begin{array}{l}195.75 \pm \\
132.28\end{array}$ & $92.80 \pm 8.3$ \\
\hline & $\mathrm{P}$ & 0.431 & $<0.001$ & 0.318 & 0.287 & 0.657 & 0.226 & 0.226 & 0.560 & 0.122 & 0.067 \\
\hline \multirow[t]{4}{*}{ Age } & Yong & $\begin{array}{l}1220.60 \pm \\
432.39\end{array}$ & $\begin{array}{l}184.20 \pm \\
96.01\end{array}$ & $\begin{array}{l}239.06 \pm \\
178.45\end{array}$ & $\begin{array}{l}665.40 \pm \\
311.44\end{array}$ & $\begin{array}{l}464.27 \pm \\
211.49\end{array}$ & $\begin{array}{l}70.42 \pm \\
12.80\end{array}$ & $\begin{array}{l}450.16 \pm \\
161.82\end{array}$ & $\begin{array}{l}28.35 \\
\pm \\
12.75\end{array}$ & $\begin{array}{l}207.01 \pm \\
186.37\end{array}$ & $95.36 \pm 4.3$ \\
\hline & Middle & $\begin{array}{l}1274.92 \pm \\
452.69\end{array}$ & $\begin{array}{l}193.84 \pm \\
103.67\end{array}$ & $\begin{array}{l}261.69 \pm \\
203.82\end{array}$ & $\begin{array}{l}745.08 \pm \\
269.35\end{array}$ & $\begin{array}{l}449.80 \pm \\
219.66\end{array}$ & $\begin{array}{l}73.16 \pm \\
12.48\end{array}$ & $\begin{array}{l}542.60 \pm \\
217.98\end{array}$ & $\begin{array}{l}25.27 \\
\pm \\
12.33\end{array}$ & $\begin{array}{l}190.65 \pm \\
122.15\end{array}$ & $92.76 \pm 8.4$ \\
\hline & Elder & $\begin{array}{l}1239.03 \pm \\
460.52\end{array}$ & $\begin{array}{l}178.59 \pm \\
94.77\end{array}$ & $\begin{array}{l}279.02 \pm \\
225.75\end{array}$ & $\begin{array}{l}757.07 \pm \\
323.13\end{array}$ & $\begin{array}{l}427.96 \pm \\
208.82\end{array}$ & $\begin{array}{l}74.29 \pm \\
13.17\end{array}$ & $\begin{array}{l}550.16 \pm \\
227.77\end{array}$ & $\begin{array}{l}22.84 \\
\pm \\
11.88\end{array}$ & $\begin{array}{l}175.23 \pm \\
121.60\end{array}$ & $91.73 \pm 9.7$ \\
\hline & $\mathrm{P}$ & 0.688 & 0.550 & 0.446 & 0.152 & 0.425 & 0.275 & 0.077 & 0.055 & 0.338 & 0.121 \\
\hline \multirow[t]{4}{*}{$\begin{array}{l}\text { Allergic } \\
\text { history }\end{array}$} & Antibiotic & $\begin{array}{l}1247.95 \pm \\
325.87\end{array}$ & $\begin{array}{l}179.33 \pm \\
111.83\end{array}$ & $\begin{array}{l}213.09 \pm \\
121.54\end{array}$ & $\begin{array}{l}714.35 \pm \\
243.96\end{array}$ & $\begin{array}{l}447.59 \pm \\
190.59\end{array}$ & $\begin{array}{l}75.65 \pm \\
11.83\end{array}$ & $\begin{array}{l}533.42 \\
\pm \\
183.06\end{array}$ & $\begin{array}{l}21.00 \\
\pm \\
11.73\end{array}$ & $\begin{array}{l}159.85 \\
\pm \\
119.09\end{array}$ & $91.83 \pm 10$ \\
\hline & Other & $\begin{array}{l}1397.30 \pm \\
255.23\end{array}$ & $\begin{array}{l}286.59 \pm \\
60.68\end{array}$ & $\begin{array}{l}245.97 \pm \\
195.28\end{array}$ & $\begin{array}{l}834.23 \pm \\
210.96\end{array}$ & $\begin{array}{l}475.6 \pm \\
76.96\end{array}$ & $\begin{array}{l}69.81 \pm \\
9.10\end{array}$ & $\begin{array}{l}590.88 \\
\pm \\
217.92\end{array}$ & $\begin{array}{l}28.21 \\
\pm \\
10.03\end{array}$ & $\begin{array}{l}226.12 \\
\pm 79.85\end{array}$ & $94.97 \pm 2$. \\
\hline & No & $\begin{array}{l}1245.96 \pm \\
478.24\end{array}$ & $\begin{array}{l}184.37 \pm \\
96.29\end{array}$ & $\begin{array}{l}260.92 \pm \\
195.87\end{array}$ & $\begin{array}{l}752.53 \pm \\
319.46\end{array}$ & $\begin{array}{l}433.62 \pm \\
209.25\end{array}$ & $\begin{array}{l}73.03 \pm \\
13.24\end{array}$ & $\begin{array}{l}540.24 \\
\pm \\
231.06\end{array}$ & $\begin{array}{l}24.81 \\
\pm \\
12.38\end{array}$ & $\begin{array}{l}188.6 \pm \\
131.45\end{array}$ & $92.42 \pm 8.8$ \\
\hline & $\mathrm{P}$ & 0.431 & 0.018 & 0.568 & 0.527 & 0.417 & 0.323 & 0.780 & 0.138 & 0.158 & 0.975 \\
\hline \multirow[t]{3}{*}{ Surgery } & Yes & $\begin{array}{l}1285.26 \pm \\
471.23\end{array}$ & $\begin{array}{l}182.04 \pm \\
95.87\end{array}$ & $\begin{array}{l}269.73 \pm \\
203.91\end{array}$ & $\begin{array}{l}749.71 \pm \\
321.18\end{array}$ & $\begin{array}{l}461.57 \pm \\
221.21\end{array}$ & $\begin{array}{l}73.04 \pm \\
14.00\end{array}$ & $\begin{array}{l}531.97 \pm \\
210.35\end{array}$ & $\begin{array}{l}24.12 \\
\pm \\
12.70\end{array}$ & $\begin{array}{l}185.17 \pm \\
136.17\end{array}$ & $91.56 \pm 9.3$ \\
\hline & No & $\begin{array}{l}1231.11 \pm \\
436.88\end{array}$ & $\begin{array}{l}187.04 \pm \\
98.35\end{array}$ & $\begin{array}{l}245.17 \pm \\
178.12\end{array}$ & $\begin{array}{l}752.79 \pm \\
294.67\end{array}$ & $\begin{array}{l}421.08 \pm \\
203.97\end{array}$ & $\begin{array}{l}73.73 \pm \\
11.76\end{array}$ & $\begin{array}{l}553.58 \pm \\
238.93\end{array}$ & $\begin{array}{l}24.55 \\
\pm \\
11.76\end{array}$ & $\begin{array}{l}186.15 \pm \\
121.17\end{array}$ & $93.30 \pm 8.5$ \\
\hline & $\mathrm{P}$ & 0.428 & 0.866 & 0.272 & 0.708 & 0.098 & 0.898 & 0.456 & 0.552 & 0.653 & 0.141 \\
\hline \multirow[t]{3}{*}{$\begin{array}{l}\text { History of } \\
\text { diseases }\end{array}$} & No & $\begin{array}{l}1301.63 \pm \\
413.78\end{array}$ & $\begin{array}{l}187.44 \pm \\
97.57\end{array}$ & $\begin{array}{l}294.99 \pm \\
271.76\end{array}$ & $\begin{array}{l}752.48 \pm \\
256.8\end{array}$ & $\begin{array}{l}462.89 \pm \\
233.94\end{array}$ & $\begin{array}{l}73.22 \pm \\
12.76\end{array}$ & $\begin{array}{l}545.68 \pm \\
193.04\end{array}$ & $\begin{array}{l}25.08 \\
\pm \\
12.72\end{array}$ & $\begin{array}{l}193.87 \pm \\
139.93\end{array}$ & $91.08 \pm 8.9$ \\
\hline & Yes & $\begin{array}{l}1234.46 \pm \\
470.19\end{array}$ & $\begin{array}{l}183.60 \pm \\
96.63\end{array}$ & $\begin{array}{l}252.92 \pm \\
188.98\end{array}$ & $\begin{array}{l}747.32 \pm \\
322.23\end{array}$ & $\begin{array}{l}431.22 \pm \\
204.75\end{array}$ & $\begin{array}{l}73.54 \pm \\
13.19\end{array}$ & $\begin{array}{l}539.69 \pm \\
233.47\end{array}$ & $\begin{array}{l}23.99 \\
\pm \\
12.24\end{array}$ & $\begin{array}{l}181.21 \pm \\
124.61\end{array}$ & $93.01 \pm 8.9$ \\
\hline & $\mathrm{P}$ & 0.318 & 0.670 & 0.196 & 0.600 & 0.453 & 0.808 & 0.566 & 0.601 & 0.468 & 0.043 \\
\hline \multirow[t]{4}{*}{$\begin{array}{l}\text { Smoking } \\
\text { history }\end{array}$} & No & $\begin{array}{l}1249.36 \pm \\
463.71\end{array}$ & $\begin{array}{l}194.16 \pm \\
98.74\end{array}$ & $\begin{array}{l}240.88 \pm \\
167.3\end{array}$ & $\begin{array}{l}744.68 \pm \\
317.46\end{array}$ & $\begin{array}{l}436.33 \pm \\
214.38\end{array}$ & $\begin{array}{l}72.58 \pm \\
13.3\end{array}$ & $\begin{array}{l}528.07 \pm \\
217.8\end{array}$ & $\begin{array}{l}25.19 \\
\pm \\
12.45\end{array}$ & $\begin{array}{l}191.36 \pm \\
137.93\end{array}$ & $92.66 \pm 8.7$ \\
\hline & Yes & $\begin{array}{l}1395.45 \pm \\
460.14\end{array}$ & $\begin{array}{l}204.81 \pm \\
106.52\end{array}$ & $\begin{array}{l}267.17 \pm \\
174.27\end{array}$ & $\begin{array}{l}854.83 \pm \\
322.1\end{array}$ & $\begin{array}{l}471.48 \pm \\
185.99\end{array}$ & $\begin{array}{l}74.52 \pm \\
11.83\end{array}$ & $\begin{array}{l}541.63 \pm \\
201.09\end{array}$ & $\begin{array}{l}22.63 \\
\pm \\
11.47\end{array}$ & $\begin{array}{l}167.39 \pm \\
103.98\end{array}$ & $91.2 \pm 9.42$ \\
\hline & Cessation & $\begin{array}{l}1220.78 \pm \\
388.34\end{array}$ & $\begin{array}{l}151.82 \pm \\
90.12\end{array}$ & $\begin{array}{l}329.4 \pm \\
260.19\end{array}$ & $\begin{array}{l}728.75 \pm \\
246.2\end{array}$ & $\begin{array}{l}441.08 \pm \\
209.86\end{array}$ & $\begin{array}{l}75.07 \pm \\
12.07\end{array}$ & $\begin{array}{l}634.99 \pm \\
265.64\end{array}$ & $\begin{array}{l}23.24 \\
\pm \\
12.14\end{array}$ & $\begin{array}{l}204.1 \pm \\
122.55\end{array}$ & $93.16 \pm 9.4$ \\
\hline & $\mathrm{P}$ & 0.124 & 0.007 & 0.170 & 0.086 & 0.343 & 0.527 & 0.062 & 0.382 & 0.377 & 0.136 \\
\hline \multirow[t]{3}{*}{$\begin{array}{l}\text { Drinking } \\
\text { history }\end{array}$} & No & $\begin{array}{l}1261.05 \pm \\
464.45\end{array}$ & $\begin{array}{l}194.59 \pm \\
103.37\end{array}$ & $\begin{array}{l}248.44 \pm \\
175.23\end{array}$ & $\begin{array}{l}752.68 \pm \\
323.32\end{array}$ & $\begin{array}{l}451.27 \pm \\
223.03\end{array}$ & $\begin{array}{l}73.12 \pm \\
13.24\end{array}$ & $\begin{array}{l}541.44 \pm \\
234.83\end{array}$ & $\begin{array}{l}24.47 \\
\pm \\
12.37\end{array}$ & $\begin{array}{l}185.61 \pm \\
130.73\end{array}$ & $92.61 \pm 9.0$ \\
\hline & Yes & $\begin{array}{l}1261.86 \pm \\
459.97\end{array}$ & $\begin{array}{l}160.90 \pm \\
77.59\end{array}$ & $\begin{array}{l}303.90 \pm \\
251.43\end{array}$ & $\begin{array}{l}762.52 \pm \\
255.07\end{array}$ & $\begin{array}{l}409.57 \pm \\
187.12\end{array}$ & $\begin{array}{l}77.26 \pm \\
14.85\end{array}$ & $\begin{array}{l}528.60 \pm \\
176.76\end{array}$ & $\begin{array}{l}20.22 \\
\pm \\
14.72\end{array}$ & $\begin{array}{l}151.40 \pm \\
132.36\end{array}$ & $91.04 \pm 6.8$ \\
\hline & Abstinence & $\begin{array}{l}1193.52 \pm \\
242.43\end{array}$ & $\begin{array}{l}124.90 \pm \\
67.65\end{array}$ & $\begin{array}{l}219.10 \pm \\
116.42\end{array}$ & $\begin{array}{l}698.20 \pm \\
219.11\end{array}$ & $\begin{array}{l}426.90 \pm \\
104.67\end{array}$ & $\begin{array}{l}72.98 \pm \\
12.51\end{array}$ & $\begin{array}{l}547.67 \pm \\
185.77\end{array}$ & $\begin{array}{l}25.24 \\
\pm \\
12.38\end{array}$ & $\begin{array}{l}200.74 \pm \\
131.11\end{array}$ & $91.99 \pm 8.7$ \\
\hline
\end{tabular}




\begin{tabular}{|c|c|c|c|c|c|c|c|c|c|c|c|}
\hline & $\mathrm{P}$ & 0.902 & 0.020 & 0.651 & 0.589 & 0.542 & 0.454 & 0.738 & 0.364 & 0.312 & 0.291 \\
\hline \multirow[t]{5}{*}{ ECOG PS } & 0 & $\begin{array}{l}1249.01 \pm \\
470.92\end{array}$ & $\begin{array}{l}189.54 \pm \\
97.22\end{array}$ & $\begin{array}{l}256.76 \pm \\
188.20\end{array}$ & $\begin{array}{l}755.79 \pm \\
314.37\end{array}$ & $\begin{array}{l}433.64 \pm \\
208.84\end{array}$ & $\begin{array}{l}73.07 \pm \\
13.01\end{array}$ & $\begin{array}{l}542.99 \pm \\
227.84\end{array}$ & $\begin{array}{l}24.55 \\
\pm \\
12.23\end{array}$ & $\begin{array}{l}188.23 \pm \\
130.96\end{array}$ & $92.41 \pm 9.1$ \\
\hline & 1 & $\begin{array}{l}1269.76 \pm \\
376.02\end{array}$ & $\begin{array}{l}157.46 \pm \\
88.47\end{array}$ & $\begin{array}{l}314.7 \pm \\
345.09\end{array}$ & $\begin{array}{l}723.17 \pm \\
241.1\end{array}$ & $\begin{array}{l}463.12 \pm \\
259.22\end{array}$ & $\begin{array}{l}74.22 \pm \\
12.16\end{array}$ & $\begin{array}{l}531.84 \pm \\
187.04\end{array}$ & $\begin{array}{l}24.57 \\
\pm \\
11.79\end{array}$ & $\begin{array}{l}181.96 \pm \\
110.51\end{array}$ & $93.97 \pm 5.7$ \\
\hline & 2 & $\begin{array}{l}1202.74 \pm \\
242.49\end{array}$ & $\begin{array}{l}181.56 \pm \\
165.45\end{array}$ & $\begin{array}{l}390.44 \pm \\
282.96\end{array}$ & $\begin{array}{l}632.00 \pm \\
218.54\end{array}$ & $\begin{array}{l}422.78 \pm \\
129.95\end{array}$ & $\begin{array}{l}77.45 \pm \\
16.10\end{array}$ & $\begin{array}{l}462.00 \pm \\
79.90\end{array}$ & $\begin{array}{l}19.88 \\
\pm \\
15.63\end{array}$ & $\begin{array}{l}153.11 \pm \\
176.08\end{array}$ & $88.14 \pm 14$ \\
\hline & 3 & $\begin{array}{l}1268 \pm \\
534.57\end{array}$ & $\begin{array}{l}257 \pm \\
96.17\end{array}$ & $\begin{array}{l}312 \pm \\
91.92\end{array}$ & $\begin{array}{l}633.5 \pm \\
297.69\end{array}$ & $\begin{array}{l}589 \pm \\
260.22\end{array}$ & $\begin{array}{l}90.59 \pm \\
3.75\end{array}$ & $\begin{array}{l}579.5 \pm \\
293.45\end{array}$ & $\begin{array}{l}7.69 \pm \\
4.51\end{array}$ & $\begin{array}{l}42.00 \pm \\
5.66\end{array}$ & $96.05 \pm 0.4$ \\
\hline & $\mathrm{P}$ & 0.966 & 0.093 & 0.267 & 0.541 & 0.776 & 0.138 & 0.779 & 0.115 & 0.075 & 0.881 \\
\hline \multirow[t]{4}{*}{ Histology } & LAC & $\begin{array}{l}1239.83 \pm \\
463.04\end{array}$ & $\begin{array}{l}186.72 \pm \\
98.1\end{array}$ & $\begin{array}{l}262.97 \pm \\
207.77\end{array}$ & $\begin{array}{l}741.78 \pm \\
309.04\end{array}$ & $\begin{array}{l}432.47 \pm \\
215.11\end{array}$ & $\begin{array}{l}73.16 \pm \\
12.97\end{array}$ & $\begin{array}{l}533.68 \pm \\
223.57\end{array}$ & $\begin{array}{l}24.59 \\
\pm \\
12.26\end{array}$ & $\begin{array}{l}185.23 \pm \\
129.68\end{array}$ & $92.36 \pm 9.2$ \\
\hline & LSC & $\begin{array}{l}1355.94 \pm \\
346.96\end{array}$ & $\begin{array}{l}161.44 \pm \\
98.52\end{array}$ & $\begin{array}{l}308.93 \pm \\
241.53\end{array}$ & $\begin{array}{l}766.33 \pm \\
231.97\end{array}$ & $\begin{array}{l}508.07 \pm \\
182.7\end{array}$ & $\begin{array}{l}78.18 \pm \\
10.83\end{array}$ & $\begin{array}{l}593.22 \pm \\
184.44\end{array}$ & $\begin{array}{l}19.62 \\
\pm \\
10.23\end{array}$ & $\begin{array}{l}157.22 \pm \\
97.15\end{array}$ & $92.73 \pm 5.5$ \\
\hline & LASC & 1562.36 & 298.00 & 909.00 & 1060.00 & 459.00 & 54.34 & 576.00 & 44.72 & 474.00 & 100.00 \\
\hline & $\mathrm{P}$ & 0.189 & 0.111 & 0.206 & 0.299 & 0.071 & 0.034 & 0.189 & 0.034 & 0.178 & 0.132 \\
\hline \multirow[t]{5}{*}{$\begin{array}{l}\text { Tumor } \\
\text { stage }\end{array}$} & $\mathrm{T} 1$ & $\begin{array}{l}1287.03 \pm \\
461.46\end{array}$ & $\begin{array}{l}199.48 \pm \\
97.84\end{array}$ & $\begin{array}{l}251.40 \pm \\
185.00\end{array}$ & $\begin{array}{l}771.03 \pm \\
306.11\end{array}$ & $\begin{array}{l}452.45 \pm \\
209.34\end{array}$ & $\begin{array}{l}72.5 \pm \\
12.94\end{array}$ & $\begin{array}{l}548.64 \pm \\
209.38\end{array}$ & $\begin{array}{l}25.08 \\
\pm \\
12.12\end{array}$ & $\begin{array}{l}195.9 \pm \\
134.25\end{array}$ & $92.84 \pm 8.0$ \\
\hline & $\mathrm{T} 2$ & $\begin{array}{l}1132.15 \pm \\
467.27\end{array}$ & $\begin{array}{l}151.1 \pm \\
86.35\end{array}$ & $\begin{array}{l}237.71 \pm \\
174.92\end{array}$ & $\begin{array}{l}651.4 \pm \\
307.11\end{array}$ & $\begin{array}{l}393.92 \pm \\
221.18\end{array}$ & $\begin{array}{l}75.83 \pm \\
11.66\end{array}$ & $\begin{array}{l}486.99 \pm \\
232.91\end{array}$ & $\begin{array}{l}22.24 \\
\pm \\
11.46\end{array}$ & $\begin{array}{l}151.16 \pm \\
110.95\end{array}$ & $91.5 \pm 9.2$ \\
\hline & T3 & $\begin{array}{l}1249.3 \pm \\
474.78\end{array}$ & $\begin{array}{l}138.25 \pm \\
67.27\end{array}$ & $\begin{array}{l}306.25 \pm \\
230.88\end{array}$ & $\begin{array}{l}766.37 \pm \\
303.9\end{array}$ & $\begin{array}{l}410.42 \pm \\
206.36\end{array}$ & $\begin{array}{l}78.33 \pm \\
10.56\end{array}$ & $\begin{array}{l}598.67 \pm \\
258.33\end{array}$ & $\begin{array}{l}20.01 \\
\pm \\
10.82\end{array}$ & $\begin{array}{l}155.53 \pm \\
92.08\end{array}$ & $93.41 \pm 5.1$ \\
\hline & $\mathrm{T} 4$ & $\begin{array}{l}1226.94 \pm \\
342.63\end{array}$ & $\begin{array}{l}167.96 \pm \\
107.62\end{array}$ & $\begin{array}{l}349.64 \pm \\
223.54\end{array}$ & $\begin{array}{l}725.14 \pm \\
207.8\end{array}$ & $\begin{array}{l}427 \pm \\
229.09\end{array}$ & $\begin{array}{l}75.31 \pm \\
12.43\end{array}$ & $\begin{array}{l}541.55 \pm \\
176.54\end{array}$ & $\begin{array}{l}22.98 \\
\pm \\
12.26\end{array}$ & $\begin{array}{l}170.36 \pm \\
102.28\end{array}$ & $92.89 \pm 9.0$ \\
\hline & $\mathrm{P}$ & 0.085 & 0.002 & 0.093 & 0.033 & 0.257 & 0.142 & 0.100 & 0.188 & 0.129 & 0.923 \\
\hline \multirow[t]{5}{*}{$\begin{array}{l}\text { Lymph } \\
\text { nodes } \\
\text { metastases }\end{array}$} & NO & $\begin{array}{l}1273.8 \pm \\
446.29\end{array}$ & $\begin{array}{l}195.1 \pm \\
97.38\end{array}$ & $\begin{array}{l}251.71 \pm \\
181.65\end{array}$ & $\begin{array}{l}768.04 \pm \\
303.92\end{array}$ & $\begin{array}{l}441.54 \pm \\
198.47\end{array}$ & $\begin{array}{l}72.86 \pm \\
12.89\end{array}$ & $\begin{array}{l}549.78 \pm \\
211.12\end{array}$ & $\begin{array}{l}24.95 \\
\pm \\
12.09\end{array}$ & $\begin{array}{l}193.59 \pm \\
131.95\end{array}$ & $93.11 \pm 7.5$ \\
\hline & N1 & $\begin{array}{l}1400.43 \pm \\
633.16\end{array}$ & $\begin{array}{l}212.75 \pm \\
108.69\end{array}$ & $\begin{array}{l}282.25 \pm \\
206.57\end{array}$ & $\begin{array}{l}779.17 \pm \\
316.94\end{array}$ & $\begin{array}{l}472.25 \pm \\
267.66\end{array}$ & $\begin{array}{l}76.96 \pm \\
13.38\end{array}$ & $\begin{array}{l}583.42 \pm \\
222.68\end{array}$ & $\begin{array}{l}21.28 \\
\pm \\
13.32\end{array}$ & $\begin{array}{l}179.58 \pm \\
140.93\end{array}$ & $90.83 \pm 11$ \\
\hline & N2 & $\begin{array}{l}1241.51 \pm \\
463.87\end{array}$ & $\begin{array}{l}158.63 \pm \\
85.08\end{array}$ & $\begin{array}{l}254.33 \pm \\
146.18\end{array}$ & $\begin{array}{l}686.63 \pm \\
320.14\end{array}$ & $\begin{array}{l}477.71 \pm \\
276.70\end{array}$ & $\begin{array}{l}75.19 \pm \\
11.33\end{array}$ & $\begin{array}{l}511.32 \pm \\
248.97\end{array}$ & $\begin{array}{l}21.63 \\
\pm \\
10.81\end{array}$ & $\begin{array}{l}154.41 \pm \\
107.8\end{array}$ & $90.83 \pm 9.7$ \\
\hline & N3 & $\begin{array}{l}1068.74 \pm \\
429.88\end{array}$ & $\begin{array}{l}136.71 \pm \\
91.75\end{array}$ & $\begin{array}{l}271.63 \pm \\
179.01\end{array}$ & $\begin{array}{l}650.58 \pm \\
231.06\end{array}$ & $\begin{array}{l}360.04 \pm \\
211.56\end{array}$ & $\begin{array}{l}74.49 \pm \\
13.07\end{array}$ & $\begin{array}{l}478.46 \pm \\
182.73\end{array}$ & $\begin{array}{l}23.75 \\
\pm \\
12.99\end{array}$ & $\begin{array}{l}161.13 \pm \\
110.39\end{array}$ & $91.98 \pm 9.0$ \\
\hline & $P$ & 0.248 & 0.008 & 0.729 & 0.127 & 0.115 & 0.545 & 0.227 & 0.385 & 0.266 & 0.556 \\
\hline \multirow[t]{3}{*}{$\begin{array}{l}\text { Distant } \\
\text { metastases }\end{array}$} & MO & $\begin{array}{l}1281.78 \pm \\
462.6\end{array}$ & $\begin{array}{l}193.06 \pm \\
97.13\end{array}$ & $\begin{array}{l}254.16 \pm \\
190.11\end{array}$ & $\begin{array}{l}763.80 \pm \\
308.98\end{array}$ & $\begin{array}{l}448.96 \pm \\
214.58\end{array}$ & $\begin{array}{l}73.1 \pm \\
12.83\end{array}$ & $\begin{array}{l}548.94 \pm \\
218.46\end{array}$ & $\begin{array}{l}24.6 \pm \\
12.05\end{array}$ & $\begin{array}{l}190.51 \pm \\
131\end{array}$ & $93.00 \pm 7.8$ \\
\hline & M1 & $\begin{array}{l}1141.48 \pm \\
396.68\end{array}$ & $\begin{array}{l}145.72 \pm \\
90.52\end{array}$ & $\begin{array}{l}330.67 \pm \\
302.36\end{array}$ & $\begin{array}{l}671.32 \pm \\
279.37\end{array}$ & $\begin{array}{l}397.7 \pm \\
198.3\end{array}$ & $\begin{array}{l}75.95 \pm \\
12.17\end{array}$ & $\begin{array}{l}507.09 \pm \\
242.88\end{array}$ & $\begin{array}{l}21.89 \\
\pm \\
12.04\end{array}$ & $\begin{array}{l}149.67 \pm \\
101.18\end{array}$ & $88.73 \pm 13$ \\
\hline & $P$ & 0.099 & 0.001 & 0.049 & 0.040 & 0.121 & 0.278 & 0.103 & 0.208 & 0.049 & 0.040 \\
\hline
\end{tabular}

Table 4

relationship between inflammatory cells levels and clinicopathologic characteristics 


\begin{tabular}{|c|c|c|c|c|c|c|c|c|c|c|}
\hline & & $\begin{array}{l}\text { WBC } \\
\text { (cells/10^12ul) }\end{array}$ & $\begin{array}{l}\text { Lymphocytes } \\
\text { (cells/10^12ul) }\end{array}$ & $\begin{array}{l}\text { Monocytes } \\
\text { (cells/ul) }\end{array}$ & $\begin{array}{l}\text { Neutrophils } \\
\text { (cells/ul) }\end{array}$ & $\begin{array}{l}\text { Eosnophils } \\
\text { (cells/ul) }\end{array}$ & $\begin{array}{l}\text { Basophils } \\
\text { (cells/ul) }\end{array}$ & $\begin{array}{l}\text { RBC } \\
\text { (cells/ul) }\end{array}$ & $\begin{array}{l}\text { Hemoglobins } \\
\text { (cells/ul) }\end{array}$ & $\begin{array}{l}\text { Blo } \\
\text { plai }\end{array}$ \\
\hline \multirow[t]{3}{*}{ Gender } & Male & $7.10 \pm 2.99$ & $1.71 \pm 0.57$ & $\begin{array}{l}0.44 \pm \\
0.18\end{array}$ & $4.79 \pm 2.98$ & $\begin{array}{l}0.15 \pm \\
0.15\end{array}$ & $\begin{array}{l}0.03 \pm \\
0.02\end{array}$ & $\begin{array}{l}4.68 \pm \\
0.61\end{array}$ & $\begin{array}{l}144.94 \pm \\
13.64\end{array}$ & $\begin{array}{l}223 \\
63.1\end{array}$ \\
\hline & Female & $6.42 \pm 2.79$ & $1.76 \pm 0.62$ & $\begin{array}{l}0.33 \pm \\
0.14\end{array}$ & $4.14 \pm 2.81$ & $\begin{array}{l}0.12 \pm \\
0.13\end{array}$ & $\begin{array}{l}0.03 \pm \\
0.02\end{array}$ & $\begin{array}{l}4.37 \pm \\
0.51\end{array}$ & $\begin{array}{l}132.6 \pm \\
12.14\end{array}$ & $\begin{array}{l}231 \\
62 .\end{array}$ \\
\hline & $P$ & 0.005 & 0.693 & $<0.001$ & 0.001 & 0.006 & 0.574 & $<0.001$ & $<0.001$ & 0.2 \\
\hline \multirow[t]{4}{*}{ Age } & Yong & $6.39 \pm 2.91$ & $1.79 \pm 0.84$ & $\begin{array}{l}0.37 \pm \\
0.14\end{array}$ & $3.99 \pm 2.2$ & $0.1 \pm 0.09$ & $\begin{array}{l}0.02 \pm \\
0.01\end{array}$ & $\begin{array}{l}4.39 \pm \\
0.59\end{array}$ & $\begin{array}{l}130.24 \pm \\
21.42\end{array}$ & $\begin{array}{l}231 \\
73 .\end{array}$ \\
\hline & Middle & $7.06 \pm 3.14$ & $1.75 \pm 0.58$ & $\begin{array}{l}0.38 \pm \\
0.17\end{array}$ & $4.77 \pm 3.26$ & $\begin{array}{l}0.14 \pm \\
0.18\end{array}$ & $\begin{array}{l}0.03 \pm \\
0.02\end{array}$ & $\begin{array}{l}4.6 \pm \\
0.45\end{array}$ & $\begin{array}{l}140.82 \pm \\
13.48\end{array}$ & $\begin{array}{l}235 \\
58.1\end{array}$ \\
\hline & Elder & $6.55 \pm 2.71$ & $1.72 \pm 0.57$ & $\begin{array}{l}0.38 \pm \\
0.16\end{array}$ & $4.27 \pm 2.71$ & $\begin{array}{l}0.13 \pm \\
0.11\end{array}$ & $\begin{array}{l}0.03 \pm \\
0.01\end{array}$ & $\begin{array}{l}4.47 \pm \\
0.65\end{array}$ & $\begin{array}{l}137.71 \pm \\
12.93\end{array}$ & $\begin{array}{l}222 \\
64 .\end{array}$ \\
\hline & $P$ & 0.204 & 0.868 & 0.948 & 0.243 & 0.198 & 0.385 & 0.029 & 0.010 & 0.1 \\
\hline \multirow{4}{*}{$\begin{array}{l}\text { Allergic } \\
\text { history }\end{array}$} & Antibiotic & $6.48 \pm 3.01$ & $1.68 \pm 0.44$ & $\begin{array}{l}0.36 \pm \\
0.15\end{array}$ & $4.29 \pm 2.91$ & $\begin{array}{l}0.15 \pm \\
0.22\end{array}$ & $\begin{array}{l}0.03 \pm \\
0.02\end{array}$ & $\begin{array}{l}4.39 \pm \\
0.93\end{array}$ & $\begin{array}{l}137.84 \pm \\
13.4\end{array}$ & $\begin{array}{l}217 \\
50 .:\end{array}$ \\
\hline & Other & $8.45 \pm 5.03$ & $1.94 \pm 0.19$ & $\begin{array}{l}0.44 \pm \\
0.27\end{array}$ & $6.01 \pm 5.12$ & $\begin{array}{l}0.13 \pm \\
0.12\end{array}$ & $\begin{array}{l}0.02 \pm \\
0.01\end{array}$ & $\begin{array}{l}4.51 \pm \\
0.34\end{array}$ & $\begin{array}{l}132.83 \pm \\
18.74\end{array}$ & $\begin{array}{l}19 € \\
47.1\end{array}$ \\
\hline & No & $6.75 \pm 2.95$ & $1.72 \pm 0.63$ & $\begin{array}{l}0.38 \pm \\
0.17\end{array}$ & $4.46 \pm 2.97$ & $\begin{array}{l}0.13 \pm \\
0.13\end{array}$ & $\begin{array}{l}0.03 \pm \\
0.02\end{array}$ & $\begin{array}{l}4.54 \pm \\
0.46\end{array}$ & $\begin{array}{l}138.65 \pm \\
14.4\end{array}$ & $\begin{array}{l}22 \varepsilon \\
64.1\end{array}$ \\
\hline & $P$ & 0.413 & 0.315 & 0.750 & 0.553 & 0.782 & 0.730 & 0.891 & 0.665 & $0.3^{\circ}$ \\
\hline \multirow[t]{3}{*}{$\begin{array}{l}\text { Surgery } \\
\text { history }\end{array}$} & Yes & $6.97 \pm 3.2$ & $1.75 \pm 0.59$ & $0.4 \pm 0.18$ & $4.65 \pm 3.25$ & $\begin{array}{l}0.14 \pm \\
0.15\end{array}$ & $\begin{array}{l}0.03 \pm \\
0.02\end{array}$ & $\begin{array}{l}4.57 \pm \\
0.6\end{array}$ & $\begin{array}{l}140.82 \pm \\
15.29\end{array}$ & $\begin{array}{l}22 \mathrm{C} \\
62.1\end{array}$ \\
\hline & No & $6.53 \pm 2.72$ & $1.72 \pm 0.61$ & $\begin{array}{l}0.37 \pm \\
0.15\end{array}$ & $4.26 \pm 2.7$ & $\begin{array}{l}0.12 \pm \\
0.14\end{array}$ & $\begin{array}{l}0.03 \pm \\
0.02\end{array}$ & $\begin{array}{l}4.46 \pm \\
0.43\end{array}$ & $\begin{array}{l}135.53 \pm \\
12.88\end{array}$ & $\begin{array}{l}223 \\
62 .:\end{array}$ \\
\hline & $P$ & 0.273 & 0.422 & 0.305 & 0.190 & 0.113 & 0.640 & 0.016 & 0.001 & $0.3^{\prime}$ \\
\hline \multirow{3}{*}{$\begin{array}{l}\text { History of } \\
\text { diseases }\end{array}$} & Yes & $6.78 \pm 3.04$ & $1.84 \pm 0.66$ & $\begin{array}{l}0.38 \pm \\
0.16\end{array}$ & $4.39 \pm 2.96$ & $\begin{array}{l}0.13 \pm \\
0.16\end{array}$ & $\begin{array}{l}0.03 \pm \\
0.02\end{array}$ & $\begin{array}{l}4.59 \pm \\
0.44\end{array}$ & $\begin{array}{l}139.17 \pm \\
13.08\end{array}$ & $\begin{array}{l}224 \\
59 .\end{array}$ \\
\hline & No & $6.73 \pm 2.95$ & $1.69 \pm 0.59$ & $\begin{array}{l}0.38 \pm \\
0.17\end{array}$ & $4.48 \pm 2.99$ & $\begin{array}{l}0.13 \pm \\
0.14\end{array}$ & $\begin{array}{l}0.03 \pm \\
0.02\end{array}$ & $\begin{array}{l}4.5 \pm \\
0.56\end{array}$ & $\begin{array}{l}137.9 \pm \\
14.86\end{array}$ & $\begin{array}{l}227 \\
64.1\end{array}$ \\
\hline & $P$ & 0.624 & 0.158 & 0.909 & 0.276 & 0.558 & 0.640 & 0.484 & 0.732 & 0.7 \\
\hline \multirow[t]{4}{*}{$\begin{array}{l}\text { Smoking } \\
\text { history }\end{array}$} & No & $6.45 \pm 2.74$ & $1.72 \pm 0.61$ & $\begin{array}{l}0.35 \pm \\
0.14\end{array}$ & $4.22 \pm 2.75$ & $\begin{array}{l}0.13 \pm \\
0.14\end{array}$ & $\begin{array}{l}0.03 \pm \\
0.02\end{array}$ & $\begin{array}{l}4.48 \pm \\
0.41\end{array}$ & $\begin{array}{l}135.79 \pm \\
13.4\end{array}$ & $\begin{array}{l}22 \epsilon \\
61 .\end{array}$ \\
\hline & Yes & $8.29 \pm 3.92$ & $1.89 \pm 0.57$ & $\begin{array}{l}0.47 \pm \\
0.24\end{array}$ & $5.87 \pm 4.01$ & $\begin{array}{l}0.13 \pm \\
0.09\end{array}$ & $\begin{array}{l}0.03 \pm \\
0.02\end{array}$ & $\begin{array}{l}4.67 \pm \\
0.54\end{array}$ & $\begin{array}{l}144.21 \pm \\
15.72\end{array}$ & $\begin{array}{l}23 \varepsilon \\
69 .:\end{array}$ \\
\hline & Cessation & $7.1 \pm 2.83$ & $1.75 \pm 0.53$ & $\begin{array}{l}0.44 \pm \\
0.16\end{array}$ & $4.6 \pm 2.87$ & $\begin{array}{l}0.15 \pm \\
0.12\end{array}$ & $\begin{array}{l}0.03 \pm \\
0.02\end{array}$ & $\begin{array}{l}4.56 \pm \\
0.78\end{array}$ & $\begin{array}{l}143.95 \pm \\
13.42\end{array}$ & $\begin{array}{l}227 \\
65 .\end{array}$ \\
\hline & $P$ & 0.001 & 0.121 & $<0.001$ & 0.002 & 0.098 & 0.145 & 0.004 & $<0.001$ & 0.8 \\
\hline \multirow[t]{3}{*}{$\begin{array}{l}\text { Drinking } \\
\text { history }\end{array}$} & No & $6.61 \pm 2.96$ & $1.74 \pm 0.62$ & $\begin{array}{l}0.36 \pm \\
0.16\end{array}$ & $4.35 \pm 2.96$ & $\begin{array}{l}0.13 \pm \\
0.13\end{array}$ & $\begin{array}{l}0.03 \pm \\
0.02\end{array}$ & $\begin{array}{l}4.49 \pm \\
0.52\end{array}$ & $\begin{array}{l}136.56 \pm \\
13.76\end{array}$ & $\begin{array}{l}226 \\
65 .\end{array}$ \\
\hline & Yes & $7.5 \pm 3.11$ & $1.76 \pm 0.58$ & $\begin{array}{l}0.45 \pm \\
0.19\end{array}$ & $5.06 \pm 3.21$ & $\begin{array}{l}0.13 \pm \\
0.14\end{array}$ & $\begin{array}{l}0.03 \pm \\
0.02\end{array}$ & $\begin{array}{l}4.58 \pm \\
0.54\end{array}$ & $\begin{array}{l}142.33 \pm \\
16.02\end{array}$ & $\begin{array}{l}237 \\
56 .\end{array}$ \\
\hline & Abstinence & $5.88 \pm 0.78$ & $1.55 \pm 0.37$ & $\begin{array}{l}0.36 \pm \\
0.07\end{array}$ & $3.71 \pm 0.67$ & $\begin{array}{l}0.15 \pm \\
0.08\end{array}$ & $\begin{array}{l}0.03 \pm \\
0.01\end{array}$ & $\begin{array}{l}4.64 \pm \\
0.3\end{array}$ & $147 \pm 8.94$ & $\begin{array}{l}202 \\
44 .\end{array}$ \\
\hline
\end{tabular}




\begin{tabular}{|c|c|c|c|c|c|c|c|c|c|c|}
\hline & $P$ & 0.026 & 0.608 & 0.002 & 0.066 & 0.399 & 0.747 & 0.267 & 0.002 & $0.2:$ \\
\hline \multirow[t]{5}{*}{ ECOG } & 0 & $6.63 \pm 2.95$ & $1.73 \pm 0.61$ & $\begin{array}{l}0.37 \pm \\
0.16\end{array}$ & $4.35 \pm 2.93$ & $\begin{array}{l}0.13 \pm \\
0.13\end{array}$ & $\begin{array}{l}0.03 \pm \\
0.02\end{array}$ & $\begin{array}{l}4.52 \pm \\
0.6\end{array}$ & $\begin{array}{l}138.95 \pm \\
13.76\end{array}$ & $\begin{array}{l}223 \\
56.1\end{array}$ \\
\hline & 1 & $7.69 \pm 3.02$ & $1.76 \pm 0.58$ & $\begin{array}{l}0.44 \pm \\
0.21\end{array}$ & $5.28 \pm 3.31$ & $\begin{array}{l}0.15 \pm \\
0.21\end{array}$ & $\begin{array}{l}0.03 \pm \\
0.02\end{array}$ & $\begin{array}{l}4.52 \pm \\
0.54\end{array}$ & $\begin{array}{l}135.51 \pm \\
17.79\end{array}$ & $\begin{array}{l}243 \\
85 .:\end{array}$ \\
\hline & 2 & $7.14 \pm 2.05$ & $1.78 \pm 0.56$ & $\begin{array}{l}0.41 \pm \\
0.09\end{array}$ & $4.78 \pm 1.57$ & $\begin{array}{l}0.12 \pm \\
0.03\end{array}$ & $\begin{array}{l}0.03 \pm \\
0.01\end{array}$ & $\begin{array}{l}4.41 \pm \\
0.47\end{array}$ & $\begin{array}{l}128.44 \pm \\
15.29\end{array}$ & $\begin{array}{l}29 \mathrm{c} \\
81 .\end{array}$ \\
\hline & 3 & $7.52 \pm 1.23$ & $1.85 \pm 0.54$ & $\begin{array}{l}0.39 \pm \\
0.09\end{array}$ & $4.96 \pm 1.5$ & $\begin{array}{l}0.27 \pm \\
0.17\end{array}$ & $\begin{array}{l}0.05 \pm \\
0.02\end{array}$ & $\begin{array}{l}4.79 \pm \\
0.2\end{array}$ & $145.5 \pm 6.36$ & $\begin{array}{l}28 \epsilon \\
30 .\end{array}$ \\
\hline & $P$ & 0.008 & 0.974 & 0.069 & 0.027 & 0.426 & 0.146 & 0.448 & 0.116 & 0.0 \\
\hline \multirow[t]{4}{*}{ Histology } & LAC & $6.65 \pm 2.88$ & $1.72 \pm 0.61$ & $\begin{array}{l}0.37 \pm \\
0.15\end{array}$ & $4.39 \pm 2.91$ & $\begin{array}{l}0.13 \pm \\
0.14\end{array}$ & $\begin{array}{l}0.03 \pm \\
0.02\end{array}$ & $\begin{array}{l}4.52 \pm \\
0.59\end{array}$ & $\begin{array}{l}138.32 \pm \\
14.25\end{array}$ & $\begin{array}{l}227 \\
63 .\end{array}$ \\
\hline & LSC & $7.5 \pm 2.99$ & $1.85 \pm 0.48$ & $0.5 \pm 0.24$ & $4.9 \pm 2.89$ & $\begin{array}{l}0.17 \pm \\
0.12\end{array}$ & $\begin{array}{l}0.03 \pm \\
0.01\end{array}$ & $\begin{array}{l}4.45 \pm \\
0.42\end{array}$ & $\begin{array}{l}136.85 \pm \\
13.66\end{array}$ & $\begin{array}{l}234 \\
59 .:\end{array}$ \\
\hline & LASC & 10.30 & 2.78 & 0.85 & 6.29 & 0.12 & 0.05 & 5.17 & 163.00 & 234 \\
\hline & $P$ & 0.076 & 0.089 & 0.002 & 0.153 & 0.078 & 0.223 & 0.173 & 0.233 & 0.81 \\
\hline \multirow[t]{5}{*}{$\begin{array}{l}\text { Tumor } \\
\text { stage }\end{array}$} & $\mathrm{T} 1$ & $6.73 \pm 3.1$ & $1.78 \pm 0.6$ & $\begin{array}{l}0.37 \pm \\
0.16\end{array}$ & $4.46 \pm 3.18$ & $\begin{array}{l}0.12 \pm \\
0.11\end{array}$ & $\begin{array}{l}0.03 \pm \\
0.02\end{array}$ & $\begin{array}{l}4.54 \pm \\
0.43\end{array}$ & $\begin{array}{l}139.19 \pm \\
12.52\end{array}$ & $\begin{array}{l}22 \mathrm{C} \\
50 !\end{array}$ \\
\hline & T2 & $6.07 \pm 2.75$ & $1.5 \pm 0.61$ & $\begin{array}{l}0.37 \pm \\
0.17\end{array}$ & $3.89 \pm 2.51$ & $\begin{array}{l}0.15 \pm \\
0.19\end{array}$ & $\begin{array}{l}0.03 \pm \\
0.02\end{array}$ & $\begin{array}{l}4.39 \pm \\
0.83\end{array}$ & $\begin{array}{l}136.91 \pm \\
16.88\end{array}$ & $\begin{array}{l}212 \\
72.1\end{array}$ \\
\hline & T3 & $7.6 \pm 2.69$ & $1.71 \pm 0.6$ & $0.5 \pm 0.25$ & $5.22 \pm 2.49$ & $\begin{array}{l}0.13 \pm \\
0.08\end{array}$ & $\begin{array}{l}0.04 \pm \\
0.02\end{array}$ & $\begin{array}{l}4.58 \pm \\
0.59\end{array}$ & $\begin{array}{l}137.56 \pm \\
17.66\end{array}$ & $\begin{array}{l}275 \\
97.1\end{array}$ \\
\hline & T4 & $7.48 \pm 1.63$ & $1.76 \pm 0.4$ & $\begin{array}{l}0.44 \pm \\
0.14\end{array}$ & $4.77 \pm 1.77$ & $\begin{array}{l}0.25 \pm \\
0.25\end{array}$ & $\begin{array}{l}0.04 \pm \\
0.02\end{array}$ & $\begin{array}{l}4.61 \pm \\
0.46\end{array}$ & $\begin{array}{l}136.77 \pm \\
16.46\end{array}$ & $\begin{array}{l}264 \\
62.1\end{array}$ \\
\hline & $P$ & 0.001 & 0.012 & 0.001 & 0.005 & 0.010 & $<0.001$ & 0.793 & 0.763 & $<0.1$ \\
\hline \multirow{5}{*}{$\begin{array}{l}\text { Lymph } \\
\text { nodes } \\
\text { metastases }\end{array}$} & No & $6.66 \pm 3.19$ & $1.76 \pm 0.6$ & $\begin{array}{l}0.37 \pm \\
0.16\end{array}$ & $4.42 \pm 3.2$ & $\begin{array}{l}0.12 \pm \\
0.11\end{array}$ & $\begin{array}{l}0.03 \pm \\
0.02\end{array}$ & $\begin{array}{l}4.52 \pm \\
0.43\end{array}$ & $\begin{array}{l}138.51 \pm \\
12.6\end{array}$ & $\begin{array}{l}221 \\
54.1\end{array}$ \\
\hline & $\mathrm{N} 1$ & $6.37 \pm 1.86$ & $1.91 \pm 0.78$ & $\begin{array}{l}0.38 \pm \\
0.17\end{array}$ & $3.8 \pm 1.4$ & $\begin{array}{l}0.19 \pm \\
0.31\end{array}$ & $\begin{array}{l}0.04 \pm \\
0.03\end{array}$ & $\begin{array}{l}4.55 \pm \\
0.47\end{array}$ & $\begin{array}{l}136.08 \pm \\
20.46\end{array}$ & $\begin{array}{l}242 \\
53 .\end{array}$ \\
\hline & N2 & $6.92 \pm 2.37$ & $1.61 \pm 0.56$ & $\begin{array}{l}0.42 \pm \\
0.21\end{array}$ & $4.56 \pm 2.33$ & $0.16 \pm 0.2$ & $\begin{array}{l}0.03 \pm \\
0.02\end{array}$ & $\begin{array}{l}4.58 \pm \\
0.47\end{array}$ & $\begin{array}{l}137.76 \pm \\
15.24\end{array}$ & $\begin{array}{l}233 \\
87.1\end{array}$ \\
\hline & N3 & $7.18 \pm 1.85$ & $1.52 \pm 0.46$ & $\begin{array}{l}0.45 \pm \\
0.14\end{array}$ & $4.67 \pm 2.21$ & $\begin{array}{l}0.19 \pm \\
0.17\end{array}$ & $\begin{array}{l}0.04 \pm \\
0.02\end{array}$ & $\begin{array}{l}4.74 \pm \\
0.46\end{array}$ & $\begin{array}{l}143.75 \pm \\
17.54\end{array}$ & $\begin{array}{l}24 \epsilon \\
69 . !\end{array}$ \\
\hline & $P$ & 0.020 & 0.238 & 0.010 & 0.096 & 0.108 & 0.041 & 0.275 & 0.447 & $0.2 i$ \\
\hline \multirow[t]{4}{*}{$\begin{array}{l}\text { Distant } \\
\text { metastases }\end{array}$} & MO & $6.68 \pm 3.08$ & $1.76 \pm 0.61$ & $\begin{array}{l}0.37 \pm \\
0.17\end{array}$ & $4.4 \pm 3.1$ & $\begin{array}{l}0.12 \pm \\
0.12\end{array}$ & $\begin{array}{l}0.03 \pm \\
0.02\end{array}$ & $\begin{array}{l}4.52 \pm \\
0.42\end{array}$ & $\begin{array}{l}138.12 \pm \\
13.03\end{array}$ & $\begin{array}{l}221 \\
54.1\end{array}$ \\
\hline & M1 & $7.13 \pm 2.1$ & $1.65 \pm 0.53$ & $\begin{array}{l}0.42 \pm \\
0.15\end{array}$ & $4.7 \pm 2.09$ & $0.2 \pm 0.21$ & $\begin{array}{l}0.04 \pm \\
0.02\end{array}$ & $\begin{array}{l}4.69 \pm \\
0.56\end{array}$ & $\begin{array}{l}140.78 \pm \\
18.37\end{array}$ & $\begin{array}{l}25 £ \\
88 .\end{array}$ \\
\hline & $P$ & 0.003 & 0.415 & 0.011 & 0.004 & 0.003 & 0.001 & 0.034 & 0.183 & 0.0 \\
\hline & LAC & nocarcinoma & nous & na; L & enos & ou & & & & \\
\hline
\end{tabular}


Figures
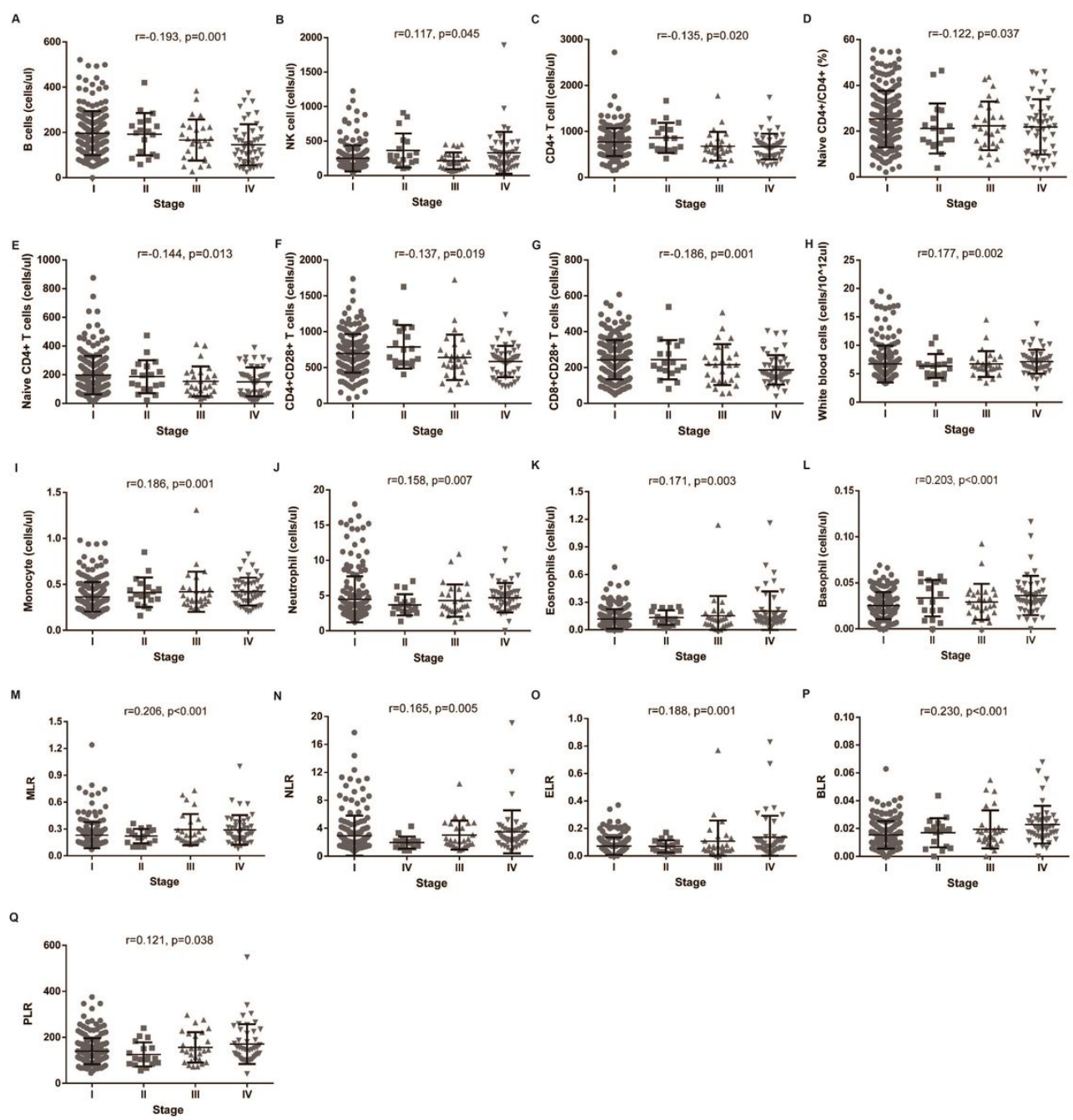

Figure 1

Predictive values of immune cells levels in progress of lung cancer. Distribution of $B$ cells counts (A), NK cells counts (B), CD4+ T cells counts (C), naïve CD4+/CD4+percentage, (D) naïve CD4+ T counts $(E), C D 4+C D 28+T$ counts $(F), C D 8+C D 28+T$ counts $(G)$, WBC counts $(H)$, monocytes counts $(I)$, neutrophils counts $(J)$, eosinophils counts $(K)$, basophils counts $(L), \operatorname{MLR}(M), N L R(N)$, ELR $(0), B L R(P), P L R(Q)$. 

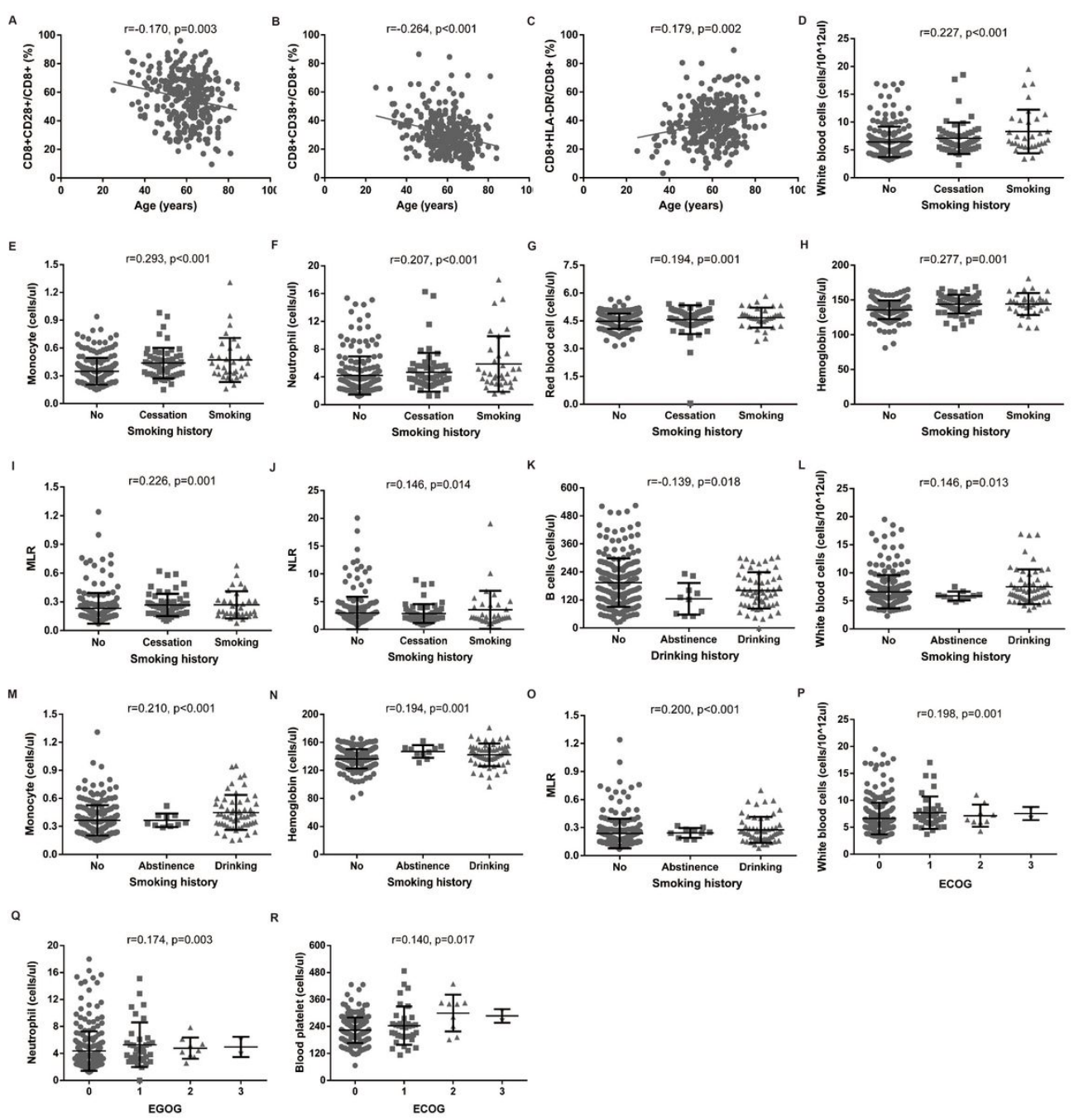

\section{Figure 2}

Relationship between immune cells levels and basic parameters for NSCLC patients. Age related change of CD8CD28/CD8+ percentage (A), CD8+CD38+/CD8+ percentage (B), CD8+HLA-DR+/CD8+ percentage (C); Smoking history related change of WBC counts (D), monocytes counts (E), neutrophils counts $(F)$, RBC counts $(G)$, hemoglobins counts $(H)$, MLR $(I)$, NLR (J); Drinking history related change of $B$ cells counts $(K)$, WBCcounts $(L)$, monocytes counts $(M)$, hemoglobins counts $(N)$, MLR $(O)$; ECOG related change of WBC counts $(P)$, neutrophils counts $(Q)$, platelets counts $(R)$. 

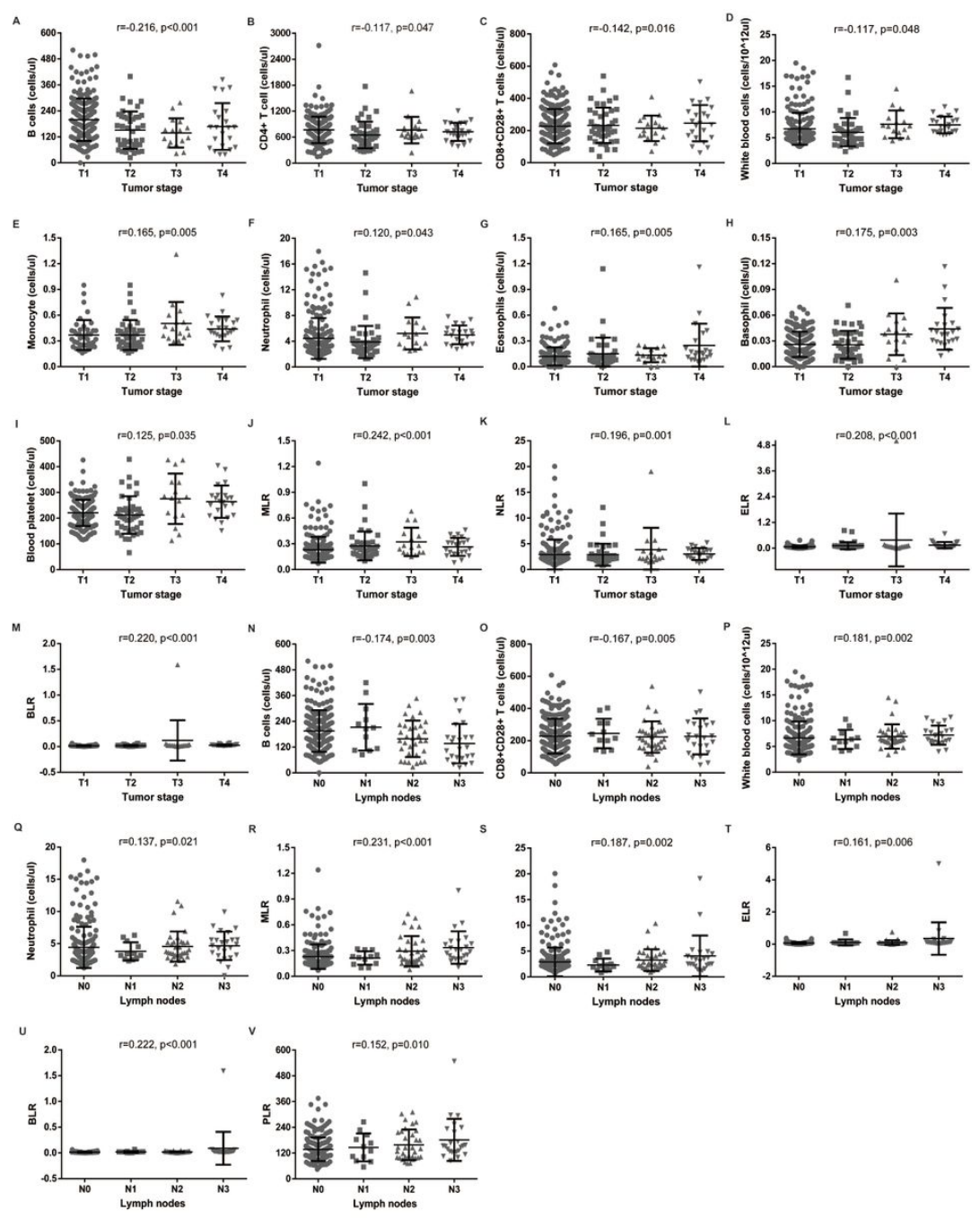

\section{Figure 3}

Relationship between immune cells levels and tumor parameters for NSCLC patients. Tumor stages related change of B cells counts (A), CD4+ T cells counts (B), WBC counts (C), monocytes counts (D), neutrophils counts (E), eosinophils counts (F), basophils counts (G), platelets counts (H), MLR (I), NLR (J), ELR (K), BLR (L); Lymph node metastasis related change of $B$ cells counts $(M), W B C$ counts $(N)$, neutrophils counts (O), MLR (P), NLR (Q), ELR (R), BLR (S); PLR (T).

\section{Supplementary Files}

This is a list of supplementary files associated with this preprint. Click to download.

- SupplementaryTable1.docx 